Revista de Estudios Histórico-Jurídicos

[Sección Historia del Derecho Español]

XXXV (Valparaíso, Chile, 2013)

[pp. 295 - 345]

\title{
LA ADMINISTRACIÓN MUNICIPAL DE JUSTICIA EN LA ESPAÑA DEL SIGLO XIX*
}

[Municipal Administration of Justice in Spain in the $19^{\text {th }}$ Century]

\author{
Francisco JaVier Díaz GonZÁlez** \\ Universidad de Alcalá, España \\ José Manuel Calderón Ortega*** \\ Universidad de Alcalá, España
}

\begin{abstract}
RESUMEN
El presente trabajo estudia la evolución que se produce a lo largo del siglo XIX en la administración de la justicia municipal española y su separación definitiva de la administración local.

Palabras Clave

Juez Conciliador - Alcalde -Juez de paz - Juez municipal.
\end{abstract}

\begin{abstract}
This article studies the evolution that occurs along the 19th Century in the Spanish Municipal administration of justice and its final separation from the local administration.

KeywOrds

Conciliation Judge - Mayor -Justice of the Peace - Municipal Judge.
\end{abstract}

RECIBIDO el 18 de abril y ACEPTADO el 22 de junio de 2013

* El presente trabajo se inserta dentro del proyecto de investigación "La simplificación del Derecho de sociedades. Política legislativa y técnica jurídica en la Unión Europea y España (II) (DER 2012-33367)".

** Profesor titular de Historia del Derecho y de las Instituciones del Departamento de Ciencias Jurídicas de la Universidad de Alcalá. Dirección postal: Facultad de Derecho, C/Libreros, 27, 28801 Alcalá de Henares (Madrid), España. Correo electrónico: fjavier.diaz@uah.es

*** Profesor titular de Historia del Derecho y de las Instituciones del Departamento de Ciencias Jurídicas de la Universidad de Alcalá. Dirección postal: Facultad de Derecho, C/Libreros, 27, 28801 Alcalá de Henares (Madrid), España. Correo electrónico: jmanuel.calderon@uah.es 


\section{INTRODUCCIÓN ${ }^{1}$}

Hasta el siglo XIX los órganos de la administración municipal desarrollaban funciones jurisdiccionales. Los primeros textos constitucionales hispánicos, la Constitución de Bayona de 1808 y la Constitución de Cádiz de 1812, siguiendo los principios imperantes de separación de poderes, prefiguran ya una Justicia "independiente" de los otros dos poderes del Estado que también se plasma a nivel local. La Constitución de Bayona menciona a los "jueces conciliadores" que formarán un "tribunal de pacificación” en su artículo 101, cuyas competencias fueron desarrolladas por la normativa posterior, concretamente por el Decreto de 21 de junio de 1812 y su Instrucción publicada de forma sucesiva en la Gaceta de Madrid los días 10 y 11 de julio de dicho año. La Constitución gaditana, por su parte, mantiene la clásica denominación castellana de "alcaldes" en su artículo 275, cuyas funciones fueron especificadas en el capítulo $3^{\circ}$ del Decreto de 9 de octubre de 1812 .

\section{LA JUSTICIA MUNiCIPAL DE LA EsPaÑA DEL REY JosÉ ${ }^{2}$}

1. El artículo 101 de la Constitución de Bayona (= CB.) establecía el orden jurisdiccional de la nueva España josefina. Dicha norma ordenaba que hubiera "jueces conciliadores que formen un tribunal de pacificación; juzgados de primera instancia; audiencias o tribunales de apelación; un tribunal de reposición para todo el reino, y una alta corte real'. Los juzgados de primera instancia sería fijados según lo exigiesen los territorios, el número de audiencias repartidas entre la Península y Ultramar oscilaría entre 9 y 15 (artículo 103 CB.), teniendo el Consejo Real la función de tribunal de reposición (artículo 104). Por su parte, la Alta Corte Real, sería encargada de conocer los delitos cometidos por individuos pertenecientes a la familia real, los ministros, los senadores y los consejeros de Estado (artículo 108). A todo ello hay que unir la supresión de las jurisdicciones especiales, especialmente las de abadengo, órdenes y señorío (artículo 98), pero se mantenía la de comercio, con sus tribunales y juntas (artículo 114).

La nueva organización judicial se inspiraba en la francesa, compuesta en primer lugar de "juges de paix", le siguen a éstos como tribunales inmediatamente superiores, los juzgados de primera instancia, "Tribunaux de première instance"; en el tercer escalón tenemos las audiencias o chancillerías, denominadas “Tribunaux

${ }^{1}$ Sobre la justicia municipal en el Antiguo Régimen, véanse: GonzÁlez Alonso, B., El corregidor castellano (1348-1808), (Madrid, 1970); LASSO GAITE, J. F., Crónica de la codificación española, I: Organización judicial (Madrid, 1998); SAINZ GuERRA, J., La Administración de justicia en España (1810-1870) (Madrid, 1992).

${ }^{2}$ Sobre la justicia municipal bonapartista, véanse: ABEBERry MAGESCAS, X., Le gouvernement central de l Espagne sous Joseph Bonaparte (1808-1813), effectivité des institutions monarchiques et de la justice royale (Paris, 2001); DE LOS Ríos, J. M., Código español del reinado intruso de José Napoleón Bonaparte (Madrid, 1845); MERCADER RiBA, J., José Bonaparte, rey de España (1808-1813). Estructura del Estado español bonapartista (Madrid, 1983); Muñoz DE Bustillo, C., Primera experiencia constitucional en Andalucía. Bayona (1808-1811) (Sevilla, 2010); Puyol MonTero, J. M., La reforma judicial de José Bonaparte, en e-S Legal History Review, 7 (2009). 
d'appel”, aunque a partir de 1804 adoptarán la denominación "Cour d'appel” y en 1810 "Cours impériales"; y, por último, en el quinto escalón de la organización jerárquica y en la cúspide de la pirámide, tenemos como suprema instancia con competencia territorial general, el Tribunal de Reposición, denominado "Tribunal de Cassation o Cour de Cassation". Finalmente, la Alta Corte Real coincidía con la "Haute Cour" francesa, teniendo ésta sus mismas competencias y composición.

No cabe que estas medidas ponían en orden la caótica situación de la organización judicial de la España del Antiguo Régimen, pero las vicisitudes de la Guerra de la Independencia, junto con la derrota francesa, hicieron inviables las medidas tomadas por el gobierno afrancesado.

Después de la toma de Madrid en diciembre de 1808, Napoleón repuso a su hermano José de nuevo en el trono el 22 de enero de 1809, que lo había abandonado a finales de julio tras la victoria española de Bailén (19 de julio de 1808). Se abría así un período en el cual el rey junto con sus ministros españoles afrancesados, intentaría aplicar las reformas que introducía el estatuto de Bayona.

2. No es objeto de este trabajo estudiar las reformas judiciales emprendidas por el rey José, concretándonos tan solamente en la esfera municipal.

En primer lugar hay que indicar que en aquellas zonas donde se mantuvo el poder militar francés, de forma transitoria perduraron las antiguas autoridades locales con su antigua denominación, siendo cesados de sus cargos, en virtud del Decreto de 19 de julio de 1809, aquellos que no tuviesen su designación de manos del propio rey José o de sus ministros (artículo 1).

Así continuó hasta la promulgación del Decreto de 17 de abril de 1810, en el cual indicaba el gobierno civil de los pueblos del pueblo, es decir, establecía una nueva estructura administrativa del territorio, compuesto por prefecturas, subprefecturas y municipalidades. A la cabeza de las municipalidades estaría el corregidor, auxiliado por los regidores (título $4^{\circ}$, artículo 8 del Decreto de 17 de abril de 1810). El Decreto solamente establecía las competencias de gobierno de esta figura, subordinada enteramente al prefecto y, por ende, al Ministerio del Interior. La nueva organización territorial serviría para delimitar la jurisdicción de los futuros órganos jurisdiccionales previstos en el Estatuto.

No se decía en el Decreto nada de las posibles competencias judiciales del nuevo corregidor por ello, el 5 de noviembre del mismo año se promulgaba un nuevo Decreto ordenando que serían los jueces de primera instancia y los alcaldes mayores los únicos encargados de conocer las demandas judiciales, prohibiéndose su intervención en el gobierno de los pueblos (artículo 1 del Decreto de 5 noviembre de 1810), reservándose ésta a los corregidores, tal como se observaba en el Decreto de 17 de abril de 1810.

Sin embargo, no sería hasta 1812 cuando se desarrollase legislativamente el precepto contenido en el artículo $101 \mathrm{CB}$. El 21 de junio de dicho año el rey José firmaba un Decreto refrendado por Mariano Luis de Urquijo en el que se establecía la nueva organización judicial, regulando la figura de los jueces conciliadores en su título I. 
Según el artículo 1, habría un juez conciliador en cada territorio, denominado distrito, compuesto de 10 leguas cuadradas o que tuviese una población de al menos 10.000 habitantes. Cada uno de ellos podrá tener un sustituto para suplirles en caso de ausencia, enfermedad, recusación u otro impedimento (artículo 2).

Como personal auxiliar, dispondría de un escribano que daría fe de todas las actuaciones (artículo 5), nombrado por el rey a propuesta del juez de entre los diferentes escribanos reales residentes en el distrito (artículo 6). También tendría la ayuda de porteros, tal como se desprende del artículo 25. En los asuntos de policía, como veremos más adelante, actuarían como fiscales los corregidores de los pueblos o el regidor que aquel nombrare para este cargo (artículo 28).

En cuanto a los requisitos que debía de tener el juez conciliador, y su sustituto, el Decreto señala que solo debía tener la edad de 30 años cumplidos (artículo 3) y su duración en el cargo sería de tres años (artículo 4).Además, conforme al artículo 152, debía estar en posesión del título de abogado. Según el artículo 151, su nombramiento, como el resto de los componentes de los demás juzgados y tribunales del reino, debía ser realizado por el rey, no pudiendo ser privado de su cargo a no ser que mediara justa causa y de acuerdo a lo establecido en el artículo $100 \mathrm{CB}$., es decir, mediante denuncia hecha por el presidente o el procurador general del Consejo Real y deliberación motivada de dicho Consejo, sujeta a la aprobación real.

En cuanto a sus honorarios, el artículo 181 establece tres clases de jueces, según el número de habitantes del distrito. Los de primera clase, localidades cuya población no llega a 10.000 habitantes, recibirían 1.000 reales. Los de la segunda clase, poblaciones comprendidas entre 10.000 y 25.000, percibirían un salario de 1.500 reales. Finalmente, la tercera clase, aquellos que residían en lugares con más de 25.000 almas, sus honorarios serían de 2.000 reales. Los jueces conciliadores de Madrid, por su parte, percibirían 5.000. Además de este sueldo, los jueces conciliadores, los escribanos y los porteros recibían un arancel por el ejercicio de sus diferentes funciones.

Conforme a la Instrucción para los jueces conciliadores que acompañaba al Decreto, en su artículo 1 se establece que tendrían audiencias ordinarias a puerta abierta en las casas de su habitación los lunes, miércoles y viernes de cada semana, de once de la mañana a dos de la tarde, concurriendo con él el escribano y los porteros del juzgado. También estarán listos para entender de todo aquello que sucediese en el distrito, "siendo cosas de urgencia, o interesándose en ello el sosiego y tranquilidad pública, a cuyo fin tendrán siempre un portero de guardia, y el escribano deberá acudir a cualquier hora que le avisaren".

Según el Decreto, el juez conciliador ejercería sus funciones en tres ámbitos: civil, penal y policía.

a) En los asuntos civiles, su principal misión era conciliar a las partes que intentasen un juicio y, en caso de no conseguirlo, intentar remitir su contienda a arbitraje (artículo 7) antes de acudir a la vía judicial propiamente dicha. Dicha conciliación era obligatoria a todo litigante, "cualquiera que sea la importancia 
de su causa" (artículo 8) ${ }^{3}$. Si no se consiguiese la conciliación, el juez debía entregar una certificación de ello a las partes para que pudiesen utilizar su derecho (artículo 10).

Al final de cada año, los jueces conciliadores debían enviar al presidente de la Chancillería, a través del presidente del tribunal de primera instancia, una certificación del número de pleitos evitados, transigidos o remitidos a arbitraje (artículo 11).

Además de la conciliación, son competentes para conocer las demandas civiles sobre bienes muebles hasta el importe de 200 reales sin apelación, y con ella hasta la suma de 1.000 (artículo 12). Las sentencias que fuesen apeladas deberían ser ejecutadas por los jueces de conciliación, precediendo siempre fianza (artículo 13).

Junto a los negocios anteriores, también conocerían sin apelación hasta el valor de 500 reales, y con apelación, en el caso de sumas mayores, los supuestos establecidos en el artículo 14, como pago de salarios, daños sobre cosas, cambio de linderos, interdictos, arreglo de inmuebles arrendados, etc. ${ }^{4}$.

En cuanto al procedimiento, tanto de los actos de conciliación como de los juicios civiles que el juez conciliador tramita, la Instrucción establece el procedimiento a seguir, distinguiendo entre juicios de tramitación verbal de juicios donde rige el principio de escritura, así como la forma en que deben de ser resueltos los recursos apelación ante sus decisiones.

El juez conciliador llevaría un libro-registro donde diariamente se anotarían los juicios verbales con expresión de la fecha, nombre de los litigantes, testigos y un breve resumen de la demanda y del fallo; el juez firmará esta nota y al margen

${ }^{3}$ Se exceptuaban de la conciliación (artículo 9 del Decreto de 1812): $1^{\circ}$ Los casos en los que dichos jueces hayan de juzgar, con apelación o sin ella; $2^{\circ}$ Las demandas que interesan al Estado, pueblo, comunidades, establecimientos públicos, mayorazgos, menores, personas intervenidas, herencias vacantes y todas aquellas en que no se puede transigir; $3^{\circ}$ Los asuntos de comercio; $4^{\circ}$ Los asuntos de intervención o fianza; $5^{\circ}$ Las de pago de alquileres, arrendamientos o atrasos de rentas y pensiones; $6^{\circ}$ Las de curiales por pago de sus honorarios; $7^{\circ}$ Las demandas contra más de dos partes, aunque tengan un interés común; $8^{\circ}$ Las demandas de comprobación, exhibición o entrega de escrituras, desaprobación o nulidad de algún acto; 9o Las de remisión a juez competente y las que se intente contra el juez conciliador que hubiere juzgado un pleito; $10^{\circ}$ Las de consignación efectiva, las de separación de bienes, y sobre tutelas y curadurías; y $11^{\circ}$ Las de embargo o desembargo de bienes y, en general, todas las ejecutivas y aquellas en que conocidamente puedan ocasionar daño la tardanza.

${ }^{4} 1^{\circ}$ Los que tratasen sobre pago de jornales y salarios de criados, cumplimiento de contratos entre maestros y oficiales y entre amos y criados. $2^{\circ}$ Sobre daños causados por personas o animales en los campos, árboles y demás plantas, frutos y cosechas. $3^{\circ}$ Daños o cambios de linderos, setos o vallados, zanjas u otros límites de heredades y los daños causados por cambios en el curso de aguas, siempre y cuando todos esos daños se hubiesen realizado dentro del año de la reclamación. $4^{\circ}$ Acciones posesorias para fijar el estado interino de la posesión. $5^{\circ}$ Demandas de inquilinos o arrendatarios contra el dueño sobre reparación de casas u otros edificios o haciendas dadas en arrendamiento; también las de los dueños contra los arrendatarios por las obras que estos deban hacer en las cosas arrendadas. $6^{\circ}$ Indemnizaciones pretendidas por los arrendatarios o inquilinos que hayan sido privados en todo o en parte del goce de las fincas arrendadas, y de los casos en que el propietario reclama menoscabos, cuando no se niega el derecho y solo se disputa la cuantía de la indemnización. 
indicará la fecha del día, mes y año respectivo (artículo 9 de la Instrucción para los jueces conciliadores inserta en el Decreto).

También en asuntos civiles los jueces civiles ordenarían embargos, fijación, reconocimiento y levantamiento de sellos sobre bienes en los casos de jurisdicción propia, en los que pueda ocasionarse perjuicios por los retrasos y en aquellos que sean ejecución de providencias de otros tribunales (artículo 15). Recibirían asimismo los juramentos de los tutores y curadores y formarían los inventarios de los bienes hereditarios en los casos de menor edad o de ausencia de los herederos (artículo 16). La jurisdicción contenciosa sobre todos estos asuntos les correspondería a otros tribunales superiores (artículo 17).

b) En los asuntos criminales, los jueces conciliadores pueden recibir las denuncias y querellas de las partes, aunque su conocimiento pertenezca a otros tribunales superiores (artículo 18). También podrán denunciar dichos delitos al fiscal general de la chancillería de la que dependan o del tribunal de corrección; asimismo, formarán las primeras diligencias en los procesos verbales y ordenar la detención de los delincuentes en caso de fragante delito o "cuando el clamor público persiga a los reos, sin perjuicio de las atribuciones de los guardas de campo y motes relativamente a los delitos cometidos en sus departamentos" (artículo 19). Las diligencias a las que se refiere esta norma consistirán, tal como se contiene en el artículo 46 de la Instrucción para los jueces conciliadores, en los casos de atentado contra la propiedad o seguridad personal de algún vecino, como robo, herida, muerte o riña, en "recibir declaración al herido, proveer a su recogimiento y curación, detener las personas indiciadas, recoger los cuerpos del delito que se encuentren, asegurar la casa o cuarto violentado, sino estuvieren habitados, hacer lo mismo con la del reo, si fuese conocido y prófugo, reconocer los lugares que fueren sospechosos en busca de los efectos robados, y cualquiera otra de esta naturaleza, con cuya omisión puede perjudicarse a la instrucción del proceso, al castigo del reo, o a la satisfacción de la parte ofendida".

El fiscal del tribunal de primera instancia es el receptor de todas las actuaciones que en el ámbito penal realizan los jueces de conciliación. Una vez realizadas las diligencias de la realización de un delito, se las enviaría en un plazo de veinticuatro horas (artículo 47 de la Instrucción); así como también los detenidos por delitos sancionados con pena corporal o infamatoria (artículo 20 del Decreto) $\mathrm{y}$, en general, todos los procesos verbales y las personas denunciadas (artículo 21 del Decreto).

c) Como jueces de policía, la tercera función que desempeñan los jueces conciliadores, conocen de todos los delitos leves cuya sanción no exceda de 60 reales de multa o cinco días de cárcel, haya o no confiscación de los objetos sobre los que recae la falta (artículo 22 del Decreto). También, según el artículo 23 del Decreto, son competentes de forma exclusiva para conocer de determinadas faltas, como las cometidas en el término municipal de la localidad cabeza de su distrito, las realizadas por transeúntes, los daños superiores a 60 reales, las infracciones de las ordenanzas de montes y plantíos, las injurias verbales, etc. ${ }^{5}$. Además, a

\footnotetext{
${ }^{5}$ Según el artículo 23 del Decreto, como jueces de policía los jueces conciliadores conocen
} 
prevención con los respectivos corregidores, serán competentes en los negocios sobre infracciones de bandos de buen gobierno, policía urbana y otras semejantes que se produzcan en el distrito (artículo 24).

El Decreto de 1812 distingue, en el desarrollo de esta labor de policía, aquellos lugares donde hay uno o varios jueces conciliadores. En el primer caso, sólo éste conocerá de todos esos asuntos, siendo auxiliado por el escribano y los porteros del juzgado (artículo 25). Cuando existan dos o más juzgados de conciliación, en cambio, cada uno de los jueces despachará el juzgado de policía de forma mensual, comenzando por el más antiguo, siendo auxiliado por un escribano particular para dicho juzgado, nombrado de la misma forma que el escribano del juzgado de conciliación (artículo 26); el juzgado de policía del supuesto anterior podrá tener dos salas, siendo cada una de ellas dirigida por un juez conciliador, teniendo el escribano un oficial habilitado para suplirle (artículo 27).

Además de hacer la función de fiscales, los corregidores de los pueblos que no sean cabeza de distrito eran competentes para conocer, a prevención de los jueces conciliadores, de aquellas faltas cometidas dentro del término municipal por las personas cogidas "in fraganti" o por las que residen o se encuentran en dicho término, siempre y cuando los daños no superen la suma de 60 reales; nunca podrían enjuiciar aquellos negocios que corresponden a los jueces conciliadores que están contenidos en el artículo 23 del Decreto (artículo 29). En estos juicios de faltas ejercerían como fiscales aquellos regidores que hubiesen sido designados; en ausencia de éste o cuando reemplazase al corregidor como juez de policía, su lugar será ocupado por uno de los miembros de la junta municipal, nombrado de forma anual por el fiscal del tribunal de primera instancia (artículo 30). Las actuaciones realizadas por el corregidor en su función de juez de policía serán registradas por un escribano, cargo ocupado por uno de los vecinos, cuya única cualidad que se exigía es que fuese "honrado" y que tomase juramente en el tribunal de corrección, es decir, en el tribunal de primera instancia (artículo 31). El corregidor, conforme al artículo 34, tendría su audiencia en la casa consistorial, oyendo en puerta abierta a las partes y a los testigos, a quienes citará por medio de avisos (artículo s 32 y 33).

Las sentencias en materia de policía serían objeto de recurso de apelación siempre y cuando ocasionen prisión o la multa exceda la suma de 60 reales, teniendo dicho recurso efecto suspensivo (artículo 35); será el tribunal de primera instancia de la subprefectura el órgano judicial competente para conocer de dichos recursos (artículo 36).

de: $1^{\circ}$ De las contravenciones cometidas en el término del pueblo de cabeza de su distrito; $2^{\circ}$ De las cometidas en los demás pueblos de su distrito, siempre que el contraventor sea persona no domiciliada o estante en aquel pueblo, o cuando los testigos que deben declarar no residen o no se encuentran a la sazón en él; 30 De las contravenciones por las cuales la parte querellosa pide la indemnización de daños y perjuicios en cantidad indeterminada o mayor de 60 reales; $4^{\circ}$ De las contravenciones a ordenanzas de montes y plantíos, en que se proceda a instancia de los particulares interesados; $5^{\circ}$ De las querellas por injurias verbales; $6^{\circ}$ De la fijación de carteles, venta, distribución o circulación de obras, escritos o estampas contrarias a las buenas costumbres; y $7^{\text {o }}$ De la persecución contra los saludadores, agoreros y otros impostores de esta clase. 
Finalmente, tanto los jueces conciliadores como los corregidores enviarían cada trimestre al fiscal del tribunal de primera instancia una relación de los autos de causas de policía que hubiesen pasado ante sus respectivos juzgados, debiendo después el fiscal depositarlo en la escribanía mayor del tribunal y enviando un extracto del mismo al fiscal general de la chancillería (artículo 38).En sus actuaciones, sí así lo estima al menos una de las partes, el juez conciliador puede ser recusado, tal como se establece en el artículo 52 de la Instrucción ${ }^{6}$, estableciéndose un procedimiento para resolver dicha incidencia ${ }^{7}$.

De esta forma estaba prevista la justicia municipal en el Decreto de 1812. Sin embargo, no tuvo prácticamente aplicación por las vicisitudes de la Guerra de la Independencia. El verano de 1812 era ya una fecha muy tardía. Pero hay que decir que sirvió de modelo para lo que vino después.

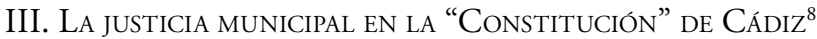 Y EN OTRAS DISPOSICIONES DE LAS CORTES DE 1812}

1. Mientras el rey José y sus ministros promulgaban las normas sobre organización de juzgados y tribunales que hemos visto en el apartado anterior, en la otra "España", las Cortes de Cádiz iniciaban una importante reforma en el Poder Judicial tomando como punto de partida postulados parecidos a los expuestos en el Estatuto de Bayona.

La primera de las normas promulgadas en materia de justicia por las Cortes de Cádiz es el Decreto de 6 de agosto de 1811, por la que incorporaba a la Nación los señoríos jurisdiccionales, suprimiendo corregidores, alcaldes mayores

${ }^{6}$ Los motivos por los que puede ser recusado un juez conciliador son: $1^{\circ}$ Cuando tenga interés personal en la demanda; $2^{\circ}$ Cuando sean parientes de alguna de las partes dentro del cuarto grado, o afines dentro del segundo; $3^{\circ} \mathrm{Si}$ en el año que ha precedido al día de la recusación, el juez conciliador o alguno de sus parientes en línea recta han tenido causa criminal con alguna de las partes; $4^{\circ} \mathrm{Si}$ el juez tiene pleito con alguna de ellas; y $5^{\circ} \mathrm{Si}$ ha dado dictamen o consejo por escrito sobre el negocio que se demanda.

${ }^{7} \mathrm{Si}$ el juez estima que es cierta la recusación, entonces ordenará que se lleve el pleito otro juez, sí existiesen varios en el lugar, o lo resuelva su sustituto (artículo 55 de la Instrucción); en caso de que no se dé por recusado o no proveyese cosa alguna, el escribano sacará testimonio del escrito de recusación y de la providencia y la enviará al fiscal del tribunal de primera instancia (artículo s 56 y 57 de la Instrucción); el fiscal dará cuenta al tribunal de los escritos, solicitando lo que estime justo y en el término de ocho días el tribunal de primera instancia dictará su decisión, comunicándolo tanto a las partes como al juez conciliador (artículo 58 de la Instrucción).

${ }^{8}$ Bibliografía básica sobre este punto: Cobos Gavala, R., El juez de paz en la ordenación jurisdiccional española (Madrid, 1989); Fernández, T. R. - SANTAMARÍA, J. A., Legislación administrativa española del siglo XIX (Madrid, 1977); GARCÍA RodríGUEZ, H., De la justicia municipal a la justicia de paz, en Revista Vasca de Derecho Procesal y Arbitraje - Zuzenbide Prozasalata Arbitraria Euskal Aldizkaria, 2 (1990); Gómez Bravo, G., Derecho y poder. Desarrollo y obstrucción a la nueva justicia en la primera mitad del siglo XIX, en Derecho y Libertades, 16 (2007); LASSO GAITE, J. F., cit. (n. 1); LoRENTE SARIN̄ENA, M. (coordinadora), De justicia de jueces a justicia de leyes. Hacia la España de 1870 (Madrid, 2006); Lorente Sariñena, M. - Martínez Pérez, F. - Solla Sastre, M. J., Historia legal de la justicia en España (1810-1978) (Madrid, 2012); Montero Aroca, J., La justicia municipal, en Estudios de Derecho Procesal (Barcelona, 1981); SAINZ GUERrA, J., cit. (n. 1). 
y demás empleados señoriales que existían en los pueblos, con la excepción de los ayuntamientos y alcaldes ordinarios, siendo aquellos sustituidos por jueces y funcionarios públicos nombrados en la misma forma que se hace en los pueblos de realengo.

El título $5^{\circ}$ de la Constitución de 1812 llevaba por título De los Tribunales y de la Administración de Justicia en lo civil y criminal, dedicando su capítulo $1^{\circ}$ a la planta judicial, concretándose en un Tribunal Supremo de Justicia con sede en la corte (artículo 259), Audiencias (artículo 262, no determinándose su número como en el Estatuto), Jueces de letras en cada cabeza de partido (artículo 273), y alcaldes en los pueblos (artículo 275).

La Constitución gaditana, como ocurría en la de Bayona, obligaba en los procesos civiles la conciliación previa antes de iniciar las actuaciones judiciales (artículo 284). Dicho cometido estaba reservado al alcalde (artículo 282), quien, reunido con dos "hombres buenos" nombrados cada uno de ellos por las partes, "se enterará de las razones en que respectivamente apoyen su intención, y tomará oido el dictamen de los dos asociados, la providencia que le parezca propia para el fin de terminar el litigio sin más progreso, como se terminará en efecto, si las partes se aquietan con esta decisión extrajudicial' (artículo 283).

En cuanto a la designación del alcalde, la Constitución de Cádiz regula dicha figura en el título 6 $6^{\circ}$ : Del gobierno interior de las provincias y de los pueblos", era elegido en el pueblo, como los otros miembros del ayuntamiento (artículo 312); la elección se haría todos los años en el mes de diciembre, reuniéndose todos los habitantes del pueblo quienes elegirían por mayoría de votos a un determinado número de electores también residentes en la localidad (artículo 313); dichos electores, también por mayoría absoluta, designarían los cargos municipales, quienes comenzarían a ejercerlos el primer día del año siguiente (artículo 314). La duración del cargo de alcalde sería de un año (artículo 315), pudiendo volver a presentarse la persona que lo ocupó a su reelección tras transcurrir un período de dos años (artículo 316).

Como cualidades necesarias para ejercer el cargo de alcalde, el artículo 317 ordena que, además de ser "ciudadano en el exercicio de sus derechos", se requiere ser mayor de 25 años y residir en la localidad al menos cinco, remitiendo a la legislación posterior las calidades que se estimasen pertinentes. No podrán ejercer de alcaldes ni de otro cargo municipal los empleados públicos de nombramiento real, con la excepción de los miembros de las milicias nacionales (artículo 318).

2. Las Cortes de Cádiz nombraron una Comisión en su seno para que redactasen un proyecto de ley sobre la nueva organización de las audiencias y de los juzgados de primera instancia, que fue presentado a las Cortes el 15 de mayo de 1812. Con referencia a las competencias judiciales de los alcaldes, además de reconocer su papel de juez de conciliaciones previsto en la Constitución, les recomendaban conocer de los juicios verbales de menor cuantía de carácter civil así como los de injurias y faltas leves en materia criminal; a ello sumaba la práctica de diligencias judiciales no contenciosas, las contenciosas con carácter urgente, o porque dependen de términos fatales o porque las circunstancias no permitan 
acudir al juez del partido y se evitaría un riesgo inminente, pues, afirmaba la Comisión "ningún perjuicio resulta de esta disposición, puesto que hecho contencioso el negocio en el primer caso y evacuada la diligencia urgente en el segundo, ha de pasar todo al juez de letras: y privar de esta facultad a los alcaldes sería muy incómodo y gravoso a los vecinos de los pueblos". También recomendaba la Comisión que los alcaldes comenzasen las primeras diligencias de los sumarios criminales cuando se cometiese algún delito o se hallase algún delincuente en el pueblo, así como que fueran ellos los que realizasen las diligencias ordenadas por el juez del partido en los pueblos, pues "los alcaldes son unos verdaderos jueces, y como tales las personas más autorizadas para estos casos".

3. Las recomendaciones de la Comisión fueron concretadas en el Decreto de 9 de octubre de 1812, que contenía el Reglamento de las Audiencias y Juzgados de Primera Instancia. Reconocía al alcalde su faceta de conciliador, en la forma expresada en el artículo 283 de la Constitución, reafirmando la obligatoriedad de la conciliación en las demandas civiles y criminales sobre injurias, no aceptándose demandas sin el certificado de haberse intentado la misma (artículo $6^{\circ} \mathrm{del}$ capítulo $4^{\circ}$ del Reglamento). Añadía el artículo 1 del capítulo $3^{\circ}$ del Reglamento que la providencia con el resultado de la conciliación debía de manifestarse a las partes en un plazo de ocho días, siendo asentada en un libro titulado "Determinaciones de conciliación”, firmando en él el alcalde, los dos hombres buenos y los interesados, si supieren, dándose las certificaciones que se pidan. También se anotaría en el libro la manifestación de las partes que no se avinieron con la conciliación, dando también certificación de ello a quien lo solicite como prueba de haberse realizado esta actuación previa al inicio del proceso civil (artículo 2 del capítulo $3^{\circ}$ del Reglamento). Sí se solicitase la conciliación por el actor ante el alcalde competente contra una persona residente en otro lugar, el artículo 3 del capítulo $3^{\circ}$ del Reglamento ordena que se le citara por medio de oficio al juez de su residencia para que comparezca dentro de término suficiente personalmente o por medio de procurador; en caso de incomparecencia, el alcalde entregará al actor certificación de haberse intentado la conciliación. Finalmente, en materia de conciliación, si la demanda tratase sobre retención de pertenencias de un deudor que intentase sustraer o sobre un interdicto de obra nueva, " $u$ otras cosas de igual urgencia", el actor puede solicitar al alcalde tome medidas provisionales para evitar perjuicios (artículo 4 del capítulo $3^{\circ}$ del Reglamento).

En cuanto a las demandas civiles, los alcaldes conocían de todos aquellos pleitos cuya cuantía no superase los 500 reales de vellón en la Península e Islas Adyacentes y de 100 pesos fuertes en Ultramar. El alcalde estaría asesorado por "dos hombres buenos" nombrados respectivamente por cada una de las partes; el alcalde oiría al actor y después al demandado, y seguidamente el dictamen de los dos hombres buenos y a continuación dictaría ante escribano la providencia que estime justa, no habiendo apelación contra dicha decisión, que tendría que asentarla, "con expresión sucinta de los antecedentes", en un libro que debe llevar sobre los juicios verbales, firmando el alcalde, los hombres buenos y el escribano (artículo 5 del capítulo $3^{\circ}$ del Reglamento). 
El Decreto establece que también conocían de todas las diligencias judiciales de asuntos civiles hasta el momento que llegasen a ser contenciosas, remitiéndolas al juez del partido (artículo 6 del capítulo $3^{\circ}$ ); y, de forma preventiva, de aquellos asuntos contenciosos que, por urgente necesidad, no dan lugar a acudir al juez de partido, como es el caso de la prevención de un inventario, interposición de un retracto y otras actuaciones de idéntica naturaleza, "remitiéndolas al Juez, evacuado que sea el objeto" (artículo 7 del capítulo $3^{\circ}$ ).

También en asuntos criminales conocen los alcaldes en las conciliaciones por injurias (artículo 1 del capítulo $3^{\circ}$ del Reglamento), así como los juicios verbales sobre injurias y faltas leves que no merezcan otra pena que reprensión o corrección ligera, tramitándose dichos juicios en la misma forma que los de carácter civil que ya hemos visto en líneas anteriores (artículo 5 del capítulo $3^{\circ}$ del Reglamento). Por último, comenzará el alcalde las diligencias sumarias, de oficio o a instancia de parte, de los delitos cometidos en el pueblo o de encontrarse un delincuente en el lugar, ordenando el prendimiento de éste siempre que los hechos que se le imputen sean castigados con pena corporal o cuando sea aprehendido cometiendo el delito in fraganti; de todo ello dará cuenta inmediata al juez del partido, remitiéndole las actuaciones practicadas y poniendo a su disposición a los detenidos (artículo 8 del capítulo $3^{\circ}$ del Reglamento); estas actuaciones también serán realizadas por los alcaldes de los pueblos donde residan los jueces de partido, con tal de que den cuenta a éste de las mismas (artículo 9 del capítulo $3^{\circ}$ del Reglamento).

Finalmente, el artículo 10 del capítulo $3^{\circ}$ del Reglamento declaraba competentes a los alcaldes para practicar y ejecutar todas las diligencias, tanto civiles como criminales, ordenadas por los jueces de partido.

De forma provisional, hasta que fuesen nombrados por el gobierno los jueces de letras de primera instancia, en los pueblos que en ese momento no hubiera tal órgano judicial, ejercerían sus funciones los alcaldes constitucionales, de la misma forma en que lo hicieron los alcaldes ordinarios (artículo 3 del capítulo $4^{\circ}$ del Reglamento); en aquellos pueblos en los que sí había juez de letras de nombramiento regio, los alcaldes constitucionales conocerían en primera instancia a prevención de aquellos (artículo 2 del capítulo $4^{\circ}$ del Reglamento); en los pueblos que hubiese juez de letras y en los que los alcaldes no hubiesen conocido a prevención con ellos, los alcaldes constitucionales tendrían la jurisdicción civil y criminal ordinaria, tal como se establece en los artículo s 5 y 8 del capítulo $3^{\circ}$ (artículo 4 del capítulo $4^{\circ}$ ).

El retorno del absolutismo con el Real Decreto de 4 de mayo de 1814 con Fernando VII dio al traste la obra legislativa de las Cortes de Cádiz. La justicia municipal volvió al antiguo sistema de alcaldes mayores y corregidores que había imperado en España antes y, en parte, durante la Guerra de la Independencia, tal como se expone en la Real Cédula de 25 de junio de 1814, volviendo a recibir dichas denominaciones los antiguos jueces de primera instancia constitucionales. Sin embargo, los alcaldes constitucionales, en virtud de la Real Cédula citada, siguieron manteniendo sus funciones.

4. Habría que esperar hasta ese breve respiro constitucional que fue el "Trienio 
Liberal" (1820-1823) para ver de nuevo realizadas las reformas realizadas por las Cortes de Cádiz. En el ámbito de la justicia municipal se restableció el Reglamento de las Audiencias y Juzgados de Primera Instancia de 1812. Sin embargo, las terribles circunstancias del momento debido a la decadencia económica y al auge del bandolerismo hicieron que las Cortes del Trienio realizasen reformas en el ámbito de la justicia municipal. En primer lugar, el Decreto de 11 de septiembre de 1820, su artículo 9 permitía al juez de primera instancia encargar a otra persona la realización de diligencias criminales sustituyendo al alcalde cuando creyese que por "razones de bien público" no era conveniente encargárselas a éste; sin embargo, el Decreto de 3 de febrero de 1823, que recogía la Ley sobre el gobierno político-económico de las provincias, establecía la obligación de los alcaldes para practicar las primeras diligencias sobre robos, homicidios y demás delitos que se cometiesen en el pueblo y en el término del mismo, remitiéndolas posteriormente al juez competente, procediendo conforme a las leyes y a la Constitución y "sin ninguna dependencia de los gefes políticos" (artículo 200). Además, el Decreto de 3 de febrero de 1823 les reconocía jurisdicción para cobrar las contribuciones que se deben a los ayuntamientos así las deudas a favor de los propios y arbitrios, pósitos y otros fondos de los pueblos, pudiendo proceder por vía gubernativa y por vía de apremio contra los bienes del deudor (artículo s 216 y 217). Por otra parte, aunque no era competencia exclusiva del alcalde sino del secretario del ayuntamiento, llevaría éste el Registro Civil de la localidad, en la forma prevista en el futuro Código civil (artículo 7).

Otra medida del “Trienio" fue el Decreto de 18 de mayo de 1821, aprobado el 2 de junio, sobre la conciliación previa a los juicios civiles o por injurias, donde se volvía a reiterar la competencia de los alcaldes en estos asuntos (artículo 2) y obligaba a realizarla en todos los casos, aunque los demandados tuviesen los fueros especiales eclesiástico o militar (artículo $1 .^{\circ}$ ).

No era necesario practicar la conciliación ante los alcaldes en: $i$ ) juicios verbales, concurso a capellanía colativas y otras causas eclesiásticas (artículo 4); ii) causas que interesan a la Hacienda, pósitos o propios de los pueblos, establecimientos públicos, menores, a los privados de la administración de sus bienes y a las herencias vacantes (artículo 4); iii) ejecuciones de bienes para el cobro de impuestos y tasas nacionales y municipales (artículo 5); iv) interdictos de posesión, de obra, retractos, formación de inventarios y partición de herencia (artículo 6); ni $v$ ) concurso de acreedores (artículo 7).

Con la segunda vuelta del absolutismo tras la intervención de las tropas del duque de Angulema, Fernando VII derogó toda la legislación del "Trienio", volviendo de nuevo la legislación del Antiguo Régimen. 


\section{LA JUSTICIA MUNICIPAL}

HASTA LA PROMULGACIÓN DE LA “Ley DE ENJUICIAMIENTO CIVIL” DE $1855^{9}$

1. La muerte de Fernando VII en 1833 puso de nuevo en marcha las reformas interrumpidas durante el "Trienio Liberal”. La primera medida, en la que están todos los autores de acuerdo, que tiene influencia en la justicia municipal es el Real Decreto de 21 de abril de 1834, por el que se subdividen las provincias en partidos judiciales, ordenando el artículo 3 de dicha norma el cese de la labor judicial de los alcaldes, remitiendo los procesos y expedientes que en esos momentos tuvieran en sus manos a los jueces letrados cabezas de partido en el instante en que fuesen nombrados. Los corregidores y alcaldes mayores, independientemente que los pueblos donde residían fueran o no cabeza de partido, continuarían desempeñando sus funciones hasta que se tomase una nueva resolución (artículo 5). Sí la localidad no fuera cabeza de partido, los corregidores y alcaldes realizarían sus funciones sin extender su jurisdicción fuera del término de dicha localidad (artículo 4).

2. La reforma tuvo corta vida. Aunque la Real Orden de 5 de septiembre reiteraba la prohibición de los alcaldes de conocer los asuntos contenciosos, otra Real Orden publicada el 12 de febrero de 1835 volvía a reconocerles dichas competencias judiciales, justificando dichas medidas "para ocurrir a las necesidades de los pueblos en la administración de justicia con respecto a los negocios de menor cuantía, como también a la indispensable subsistencia de los Jueces de Partido de nueva creación, mientras se aprueba el arreglo definitivo de los juzgados inferiores". Establecía la nueva Real Orden, que en los pueblos donde no hubiese juez de partido, los alcaldes conocerían de pleitos cuya cuantía no fuera superior a 200 reales de vellón, teniendo la consideración de juicios verbales (artículo 1), así como de las injurias y faltas leves que solamente llevasen pena de corrección (artículo 2), practicando además las primeras diligencias de las causas criminales, dando cuenta de ello al juez del partido (artículo 3). Sí el juez de partido residiera en el pueblo, asumiría las competencias antedichas y no los alcaldes (artículo 4).

3. El nuevo ritmo de los acontecimientos marcado por la última Real Orden fue confirmado por el Real Decreto de 23 de julio de 1835 sobre el arreglo provisional de los ayuntamientos del Reino, en cuyo artículo 37 reconocía las competencias judiciales del alcalde para conocer de los juicios verbales civiles cuya cuantía no superará los 200 reales, así como de los procesos por injurias y faltas leves que lleven solamente corrección (artículo 38), siempre y cuando no residiera en la localidad el juez de partido. Practicaría las primeras diligencias de las causas criminales destinadas a esclarecer los delitos cometidos en el pueblo y a detener a los presuntos delincuentes, enviándolas a continuación al juez de

\footnotetext{
${ }^{9}$ Además de las obras reseñadas en la nota 8 , también debe consultarse para el estudio de este apartado: Arrazola, L., Enciclopedia española de Derecho y Administración o Nuevo Teatro Universal de la Legislación de España e Indias (Madrid, 1849), II; ORTIZ DE ZÚNIGA, M., El libro de los alcaldes y ayuntamientos (2a edición, Madrid, 1849); PAREDES, J., La organización de la justicia en la España liberal. Los orígenes de la carrera judicial, 1834-1870 (Madrid, 1991).
} 
partido (artículo 39). Añadía también el Real Decreto en su artículo 40, como novedad con respecto a la Real Orden, la competencia de los alcaldes para conocer de las contravenciones hechas contra los bandos u ordenanzas de gobierno, los desacatos contra su autoridad o a la de los demás miembros del ayuntamiento, siempre que la sanción no fuese superior a 100 reales de vellón o a tres días de arresto, a no ser que los bandos u ordenanzas dispusieren una pena superior; en estos casos, instruirían sumariamente los hechos pasando las actuaciones a otro órgano jurisdiccional superior (artículo 41). Finalmente, para recalcar la separación de funciones administrativas de las judiciales, el artículo 42 señala que los alcaldes dependen en este último ámbito de los jueces y tribunales, tal como determinan las leyes, y no del gobernador civil. Otra de las novedades del Real Decreto de 23 de julio de 1835 era la asunción de estas competencias por el teniente de alcalde en su cuartel o barrio de la localidad, entendiéndose con el alcalde para enviar las diligencias criminales al tribunal superior (artículo 45).

4. Junto a estas funciones meramente judiciales, hay que añadir que el Real Decreto de 23 de julio de 1835 concedía al alcalde la competencia para llevar el registro de nacidos, casados y muertos en su respectivo territorio, debiéndosele pasar por los vecinos el correspondiente aviso en el plazo de 48 horas, bajo pena de multa si se omitiese tal suceso. La misma responsabilidad tenían los directores de las casas de expósitos de enviar una nota de aviso. El libro, que era un antecedente del Registro Civil, debía custodiarse en el archivo del ayuntamiento y enviarse cada tres meses un extracto del mismo, confrontado con libros parroquiales, al gobernador civil (artículo 36, 8).

En cuanto a las cualidades personales para desempeñar el cargo de alcalde, el Real Decreto de 23 de julio de 1835 ordenaba que su titular, elegido libremente (artículo 6), por un plazo de dos años (artículo 7), debía ser ciudadano español mayor de 25 años con al menos cuatro de residencia en la provincia y dos en el pueblo, saber leer y escribir y estar inscrito en la lista de mayores contribuyentes (artículo 16).

5. La promulgación del Reglamento para la administración de justicia en lo respectivo a la jurisdicción ordinaria mediante el Real Decreto de 26 de septiembre de 1835, transcribía casi literalmente preceptos anteriores, especialmente los Decretos de 9 de octubre de 1812 y de 18 de mayo de 1821. También conviene destacar que por primera vez utiliza un término que perdurará en el tiempo: "juez de paz".

El capítulo $2^{\circ}$ del Reglamento tiene como título De los jueces y juicios de pazo actos de conciliación, y de los alcaldes de los pueblos como jueces ordinarios (artículo s 21 a 35), y se divide en dos secciones. La primera sección trataba de las conciliaciones (“Jueces y juicios de paz"), reiteraba la obligación de intentar la conciliación y constar que ésta no ha tenido efecto antes de entablar las demandas civiles y las de meras injurias, exceptuándose (artículo 21): i) las causas sobre la Real Hacienda, pósitos o propios de los pueblos, fondos y establecimientos públicos, herencias vacantes o de menores y de los que se hallan privados de la administración de 
sus bienes; ii) los negocios que deben conocerse en juicio verbal, interdictos, concurso de acreedores, denuncias de obra nueva, tanteos o retractos, retenciones de gracias, formación de inventario o partición de bienes u "otros casos urgentes de semejante naturaleza".

Competentes para conocer las conciliaciones como jueces de paz eran los alcaldes y los tenientes de alcaldes de cada pueblo (artículo 22), quienes se reunirían con dos hombres buenos nombrados por cada parte, escuchando las alegaciones de las partes o de sus apoderados y, junto al dictamen de los hombres buenos, dictará la providencia de conciliación en un plazo de cuatro días, asentándose en un libro titulado "juicios de paz" y firmando en él los hombres buenos y los interesados si supiesen escribir, dando las certificaciones que se soliciten (artículo 23). Sí las partes aceptan la conciliación, el pleito finaliza allí (artículo 24), pero sí alguna o las dos no están de acuerdo, el juez de paz les exhortará a que acudan a un árbitro y, sí aun así esto no les conviniese, dará la certificación de haberse intentado la conciliación y que no ha habido avenencia (artículo 25). Se reitera la obligación del demandado de acudir al acto de conciliación, aunque viva en otra población, pues para ello el juez de paz le citará por medio de oficio dirigido a la justicia del lugar, señalando un término suficiente. Sí no compareciese, entonces se le multará de 20 a 100 reales de vellón, según sus circunstancias personales y se dará por terminada la conciliación, entregando al demandante certificado de haberse intentado para que pueda ejercitar su acción. La multa, en las provincias de Ultramar, podría ser doble (artículo 26). El demandante puede solicitar al juez de paz que tome medidas cautelares para retener efectos pertenecientes a un deudor que intente sustraerlos, "o sobre algún otro punto de igual urgencia", para evitar posibles perjuicios, mientras se tramita la conciliación (artículo 27). Sí el juez de paz es parte en un proceso civil o de injurias, y en la localidad no hay otro, ejercerá dicho cargo el regidor primero que siga en orden; sí lo fuere el ayuntamiento, será competente el juez de paz del pueblo más cercano (artículo 28). Por su labor, el juez de paz no percibirá derecho alguno, pero exigirá 2 reales por gastos de libros y escribiente, doblándose la suma en Ultramar, a no ser que una de las partes sea pobre de solemnidad (artículo 29).

Finalmente, el artículo 30 afirma que "Los jueces de paz, penetrándose de la importancia que interesa el que se eviten cuando sea posible los pleitos y disensiones entre los ciudadanos, pondrán la mayor eficacia en conciliar a los que se presenten ante ellos teniendo entendido que mientras más litigios y querellas corten, mayor será el servicio que hagan al Estado, y mayor el mérito que contraigan a los ojos del Gobierno".

La sección segunda, rubricada: Alcaldes y tenientes de alcaldes como jueces ordinarios, ordenaba las funciones judiciales de estos órganos municipales, conociendo "a prevención con el juez letrado de primera instancia donde le hubiere", de los juicios verbales de carácter civil cuya cuantía no superase los diez duros en la Península e Islas adyacentes, y de treinta en Ultramar, así como de los de injurias y faltas livianas que llevasen pena de reprensión. Para conocer de estos asuntos, el alcalde o teniente de alcalde se asociará con dos hombres buenos nombrados cada uno por cada parte; oídas las alegaciones de las partes y visto el dictamen de los hombres buenos, dictará una resolución que no es susceptible de apelación, 
siendo después registrada en un libro que llevará sobre los juicios verbales tramitados ante él, firmando en él el alcalde o teniente de alcalde, los hombres buenos y el escribano (artículo 31).

Como jueces ordinarios, conocerán los alcaldes y tenientes de alcalde de las diligencias judiciales en asuntos civiles hasta que lleguen a ser contenciosos, debiendo remitirlas al juez letrado de primera instancia; también podrán practicar, a instancia de parte, aquellas diligencias urgentísimas a las que no de tiempo de acudir a solicitarlas al juez letrado competente, remitiéndolas a dicho juez "evacuado que sea el objeto en aquella parte que la urgencia requiera" (artículo 32). También los alcaldes y tenientes de alcaldes practicarán las primeras actuaciones en caso de comisión de un delito en sus pueblos o de encontrarse en ellos un delincuente, debiendo proceder a practicar, de oficio o a instancia de parte, las primeras diligencias del sumario, dando cuenta de ello al respectivo juez letrado de primera instancia, remitiéndole las actuaciones y poniendo a su disposición los delincuentes capturados. "Este conocimiento, -dice el artículo 33-, en los pueblos donde residen los jueces letrados podrán y deberán tomarle a prevención con estos los alcaldes y los tenientes de alcaldes, hasta que avisado el juez sin dilación, pueda continuar por si los procedimientos". Finalmente, las diligencias tanto civiles como criminales que deban ser practicadas en los pueblos donde no residan otros jueces ordinarios que los alcaldes, serán realizadas exclusivamente por éstos o por los tenientes de alcaldes, salvo sí el tribunal o el juez que conozca la causa principal crea conveniente encargarlas a otra persona (artículo 34).

El contenido del Reglamento provisional de la administración de justicia de 1835 fue durante veinte años la normativa básica de la justicia municipal. En este período de tiempo las vicisitudes políticas alteraron el régimen judicial español. Como consecuencia del estallido del llamado "Motín de la Granja”, por Real Decreto de 13 de agosto de 1836se reinstauraba la Constitución de 1812 y con ella el sistema judicial imperante en ella, derogando por ello el artículo 33 del Reglamento. La Constitución de Cádiz fue sustituida por la nueva de 17 de junio de 1837, que prohibía en su artículo 63 a los jueces y tribunales no ejercer más funciones que las estrictamente judiciales, entendiéndose por ello que los alcaldes no podían realizarlas; sin embargo al declararse vigente el título $5^{\circ}$ de la Constitución de 1812 por un Real Decreto de 16 de septiembre, los alcaldes mantuvieron sus competencias judiciales.

6. Mientras tanto, normas aprobadas en el "Trienio Liberal" adquirían de nuevo validez, como el Decreto de 18 de junio de 1821 sobre conciliación que fue puesto en vigor por el Real Decreto de 30 de agosto de 1836 y la Ley provincial de 1823 por el Real Decreto de 15 de octubre de 1836. Por otra parte, el Real Decreto de 29 de mayo de 1837, encargaba a los alcaldes constitucionales la conciliación en los negocios mercantiles en la misma forma que lo hacen en los demás. Sin embargo, se quiso cortar las competencias judiciales a los alcaldes. Por un lado, la Real Orden de 11 de enero de 1840, ordenaba que en los casos de atentado los alcaldes instruyeran el tiempo necesario para que el hecho pudiera llegar a conocimiento del juez del partido o que éste pudiera trasladarse al lugar donde hubiese ocurrido el desorden; también se ordenaba que si el juez de partido 
se hallase enfermo o ausente o inhabilitado para conocer de la naturaleza de los sucesos, la audiencia nombrase para su conocimiento a un letrado de reconocido prestigio en vez de dejar al alcalde realizar su labor jurisdiccional.

7. En materia de registro civil, el Real Decreto de 24 de enero de 1841, limitó el alcance de la medida establecida en el Real Decreto de 23 de julio de 1835, ordenando que sólo existiera en aquellas localidades cuya población excediera de 500 vecinos, siendo responsables los alcaldes y los secretarios de los ayuntamientos de la veracidad de lo contenido en los libros del Registro. Sin embargo, al fracasar la colaboración de las autoridades eclesiásticas en facilitar la información de los nacimientos, matrimonios y defunciones registrados en los libros parroquiales, la Real Orden de 24 de mayo de 1845 dejó sin efecto este antecedente del Registro Civil, al no obligar ni a los párrocos ni a los familiares de informar de dichos sucesos.

8. La Ley de organización y atribuciones de los ayuntamientos, promulgada por Real Decreto de 30 de noviembre de 1843, modificaba de nuevo la duración del mandato de los alcaldes y tenientes de alcaldes en sus puestos. Esta sería de un año (artículo 6), siendo elegidos por los mayores contribuyentes de la localidad (artículo 17), exigiéndose en los pueblos de más de sesenta vecinos que supiesen leer y escribir, siendo dispensada esta circunstancia por el jefe político de la provincia si lo estimase conveniente (artículo 18).

9. Entre la vigencia de la Constitución de 1837 y la de 1845 se aprobó el Real Decreto de 1 de mayo de 1844 que contenía el Reglamento de los juzgados de primera instancia, donde se concretaban las relaciones de estos órganos judiciales con los alcaldes. Según el artículo 1 los alcaldes conocerían de los juicios verbales que no excediesen de 200 reales, siempre y cuando no residiese en el pueblo juez de primera instancia, modificando de esta forma lo establecido en el Reglamento de provisional para la administración de justicia de 1835. Sin embargo, debido al exceso de pleitos de escasa cuantía que se acumulaban en los juzgados de primera instancia, este precepto fue modificado por Real Orden de 28 de octubre de 1848 , por el cual los alcaldes de los pueblos cabeza de partido vinieron de nuevo a conocer de dichos pleitos.

Las ausencias y enfermedades y vacantes de los juzgados de primera instancia serán sustituidas por los alcaldes y sus tenientes por su orden y, si de los tenientes alguno fuese letrado, sería preferido al alcalde y a los tenientes legos (artículo 7). Por su parte, en la sección $3^{a}$ (cuya rúbrica era: Relación de los jueces con los alcaldes del partido) capítulo $2^{\circ}$ (Disposiciones generales) podemos apreciar ese intento de separar la función jurisdiccional de los alcaldes y dejarles en su papel meramente gubernativo. Insistía el artículo 103 en la remisión inmediata de las diligencias a los jueces de primera instancia que realizaban los alcaldes en virtud del artículo 32 del Reglamento de 1835en el momento en que el asunto que las originaba se convirtiera en contencioso "o que haya necesidad del conocimiento del derecho para su continuación, prohibiéndose expresamente el uso de asesores innecesarios y 
costosos". Por otro lado, en lo relativo a las providencias de avenencia previstas en el artículo 24 del citado Reglamento de 1835, si se suscitase alguna tercería u otra cuestión ajena de la convenida en el juicio de paz o fuese necesario "conocimiento del derecho para su ejecución”, el alcalde o el teniente de alcalde está obligado a remitirla al juzgado de primera instancia para que la continúe (artículo 104). En cuanto a las primeras diligencias realizadas por los alcaldes por la comisión delitos o por la captura de delincuentes, tal como dice el artículo 33 del Reglamento de 1835 , los alcaldes o sus tenientes enviarán de forma rápida un oficio al juez del partido dándole cuenta del hecho o del delito, "cuya diligencia será simultánea al auto de oficio". En el caso de que dilatasen la entrega de los arrestados por algún motivo legítimo más de 24 horas, "les recibirán sus declaraciones indagatorias (artículo 105).

Teniendo en cuenta lo previsto en las normas del "Trienio Liberal”, el artículo 34 del Reglamento de 1835 y la Real Orden de 11 de enero de 1840, podemos apreciar en el artículo 106 esa predisposición de privar a los alcaldes de su función jurisdiccional, al prevenir que sí no encargasen los titulares de estos órganos judiciales la formación de las diligencias de carácter crimina previstas en el artículo $105 \mathrm{u}$ otras que les libres en otras personas diferentes al alcalde o a sus tenientes, éstos tendrían la consideración de "delegados y auxiliares de los juzgados y subordinados por lo tanto a ellos".

Finalmente, los jueces de primera instancia eran competentes para formalizar las primeras diligencias por las faltas $\mathrm{u}$ omisiones cometidas por los alcaldes o sus tenientes en el ejercicio de sus competencias judiciales, remitiéndolas posteriormente a la audiencia del territorio (artículo 107). En los demás casos, especialmente en los delitos y faltas cometidos como auxiliares del juez de primera instancia, éste será competente para enjuiciarlos, "y si la falta fuese en negocio civil que no merezca formación de causa, le corregirá guardando la moderación posible, con apercibimiento, imposición de costas a que haya lugar o alguna ligera multa, siendo apelables sus providencias (artículo 108).

10. A pesar que la Constitución de 1845 repetía en su artículo 66lo manifestado en el artículo 63 de la de 1837, los alcaldes y tenientes de alcalde mantuvieron sus funciones judiciales, tal como les había reconocido el artículo 78 de la Ley de organización y atribuciones de los ayuntamientos de 8 de enero de 1845, siendo, conforme a esta última norma, designados por el monarca en todas las capitales de provincia y en aquellas cabezas de partido que superase su población los dos mil vecinos, mientras que en el resto de las localidades serían designados por los jefes políticos provinciales. El nombramiento se haría entre los concejales elegidos por los pueblos (artículo 9), quedando reservada esta elección a los mayores contribuyentes (artículo 20). En cuanto a los requisitos personales, el artículo 21 repetía el contenido de la anterior norma de 1843.

11. La promulgación del Código Penal de 1848, por Real Decreto de 19 de marzo, volvía a reconocer las competencias judiciales en materia penal de los alcaldes y tenientes de alcaldes, al disponer la regla $3^{\text {a }}$ de la Ley provisional para la aplicación de las disposiciones del Código penal (incluida en este cuerpo legal), 
que serían los encargados de conocer los juicios verbales de las faltas contenidas en el libro III del Código. Llevarían para ello un libro foliado y rubricado donde se extendería el acta de cada juicio, siendo firmada por el alcalde o teniente de alcalde y todos los que participasen en el juicio, si supiesen firmar. Veinticuatro horas después se dictaría sentencia, siendo notificada a las partes y anotada en el libro, así como también las notificaciones. La regla $4^{\mathrm{a}}$ dispone que contra dicha sentencia quepa recurso de apelación ante el juez de primera instancia del partido, debiendo ser ejercitado este recurso en el plazo de tres días desde la notificación por parte del alcalde, quien lo admitirá si se respeta dicho término. Una vez admitido el recurso, el alcalde enviará al juez de primera instancia una copia testimoniada del acta y de la sentencia, citando y emplazando a las partes para que en un plazo de diez días acudan a usar de su derecho. A continuación de la copia testimoniada se pondría nota de haberse admitido la apelación y se extendería la diligencia de emplazamiento (regla 5a). Ejercería de fiscal en los juicios de faltas el promotor fiscal, si residiese en el pueblo o, en su lugar en caso de no residir, sería el procurador del común (regla $7^{a}$ ). Finalmente, los libros de actas previstos en la regla $3^{\text {a }}$ serían enviados por los alcaldes a los juzgados de primera instancia en los primeros quince días de enero de cada año (regla 9a). Como puede verse, podemos apreciar aquí una influencia de la anterior normativa sobre jueces de conciliación prevista por el rey José I.

El cumplimiento de estas disposiciones dio lugar a importantes dudas e interrogantes por parte de las autoridades judiciales, intentándose dar solución a las mismas mediante la Real Orden de 1 de julio de ese mismo año. En dicha norma se ordenaba que sí el número de alcaldes o tenientes de alcaldes de la población fuera mayor que el de los juzgados de primera instancia, aquellos debía ejercer la jurisdicción que les atribuye la regla $3^{\mathrm{a}}$ de la Ley provisional en sus respectivas demarcaciones (artículo 1); si la demarcación de la alcaldía se extendiera a dos o más distritos judiciales, intervendría en el juicio verbal el promotor del juzgado donde las faltas se hubieran cometido (artículo 2); finalmente, los recursos de apelación de las sentencias dictadas por los alcaldes se interpondrán ante los juzgados de primera instancia del lugar donde la falta se hubiese cometido, "aun cuando la mayor parte de la demarcación del Alcalde o Teniente de Alcalde corresponda a otro distrito judicial' (artículo 3).

12. No dio gran solución la Real Orden de 1 de julio de 1848 y meses más tarde se tuvo que promulgar un nuevo Real Decreto, fechado el 22 de septiembre, en el que se modificaban las reglas contenidas en la Ley provisional para aplicar el Código Penal, especialmente cuando los encargados eran las autoridades municipales. Su artículo 2 intercalaba nuevas reglas en la Ley. Así la nueva regla $4^{\mathrm{a}}$ no reconocía jurisdicción a los alcaldes corregidores, pues solamente eran autoridades gubernativas; la nueva regla $5^{\mathrm{a}}$ ordenaba que, para hacer compatibles las funciones gubernativas y judiciales donde hubiese alcaldes y tenientes de alcaldes, los primeros no tendrían distrito judicial especial, "conociendo sólo de las faltas a prevención con los tenientes cuando las atenciones del gobierno se lo permitan”. En el caso de no coincidir las demarcaciones municipales y judiciales, siendo desigual 
por ello el número de tenientes de alcalde y de juzgados de primera instancia, la nueva regla $\sigma^{\mathrm{a}}$ ordenaba que si el de los primeros fuese mayor, conocerían todos los tenientes, y si menor, sólo los que hubiere, observándose aquí y en la regla $5^{\mathrm{a}}$, en cuanto a la intervención fiscal y a las apelaciones, lo previsto en la Real Orden de 1 de julio de 1848; los juicios de faltas, declaraba la nueva regla $7^{\mathrm{a}}$, se celebrarían ante escribano o notario, o, en su defecto, ante el fiel de fechos; la nueva regla $12^{\text {a }}$ prescribía el deber de los jueces de primera instancia y de los promotores fiscales de cuidar que los alcaldes y tenientes de alcaldes persigan las faltas que se cometieran en sus respectivas jurisdicciones " $y$ cuyo conocimiento les atribuye la ley provisional'. Por último, señalaba el Real Decreto de 22 de septiembre de 1848 en su artículo 3 que las multas impuestas por los alcaldes o por los tenientes de alcalde procedentes de los asuntos judiciales serían ingresadas en el fondo de penas de cámara de la misma forma que las impuestas por el resto de juzgados y tribunales.

13. Poco tiempo más tarde el Código Penal de 1848 fue modificado por los Reales Decretos de 7 y 8 de junio de 1850. Este último introducía importantes novedades en las reglas contenidas en la Ley de aplicación del Código penal. Entre ellas hay que destacar que la nueva regla $3^{a}$ prohibía la admisión en los juicios de faltas de ningún género de escritos así como informes orales de letrados; sí el juicio no pudiese realizarse en un solo acto, bien por la incomparecencia de un testigo o por otro justo motivo, se continuaría al día siguiente, extendiéndose en cada uno de ellos el acta correspondiente, dictando el alcalde la sentencia en el plazo previsto de veinticuatro horas (regla $4^{\mathrm{a}}$ ); la regla $18^{\mathrm{a}}$ ordenaba que las costas en la primera instancia de los juicios verbales no excedería de la cuarta parte de la multa que se impusiese al acusado, y que este tipo de juicios no devengaría ningún tipo de derechos a favor de los jueces de primera instancia, alcaldes y tenientes de alcalde ante quienes se hubiesen suscitado. Los escribanos de las alcaldías, dice la regla 20 a , "cuidarán de distribuir en la debida proporción entre los demás funcionarios que los devengan la cantidad impuesta por condenación de costas, y de remitir al juzgado de apelación la parte que le corresponda”. En todo lo demás repetía el contenido de la Ley provisional anterior a la reforma del Código Penal. 


\section{LA “Ley de EnJuiciamiento Civil” de 1855 \\ Y LA APARICIÓN DEL JUEZ DE PAZ COMO ÓRGANO JUDICIAL INDEPENDIENTE DE LA ADMINISTRACIÓN MUNICIPAL ${ }^{10}$}

Por Real Decreto de 5 de octubre de 1855 se aprobó y promulgó la nueva Ley de Enjuiciamiento civil. Su artículo 201 atribuía a los jueces de paz la competencia exclusiva en materia de conciliación; el artículo 357 indicaba que eran competentes para practicar las diligencias necesarias de los juicios abintestato en aquellos pueblos donde no hubiese juez de primera instancia, siendo asesorados por un asesor en caso de no ser letrados; el artículo 930 les permitía acordar el embargo preventivo en los pueblos donde no hubiese juzgado de primera instancia, con dictamen de asesor, si no fuese letrado; finalmente, el artículo 1162 les ordenaba el conocimiento en primera instancia de los juicios verbales cuya cuantía no fuera superior a 600 reales. La nueva figura judicial de juez de paz fue creada días más tarde de la promulgación de la Ley de Enjuiciamiento civil, por el Real Decreto de 22 de octubre. De esta manera se separaban las funciones judiciales que antes se habían atribuido a los alcaldes.

En todos los pueblos donde hubiese ayuntamiento, conforme al artículo 1 del Real Decreto de 22 de octubre de 1855, se constituirían juzgados de paz, cuyo número sería igual al de alcaldes y tenientes de alcaldes que hubiese o hubiera en lo sucesivo, habiendo también igual número de jueces suplentes (artículo 2). El Real Decreto limitaba las atribuciones de los jueces de paz solamente al ámbito civil, no decía nada en cambio de los juicios de faltas penales.

El cargo de juez de paz sería meramente honorífico, con una duración obligatoria de dos años y gratuito, disfrutando sus titulares de la misma consideración y exenciones que los alcaldes (artículo 3). En cuanto a las cualidades que debían de ostentar la persona que ocupase el juzgado de paz o su sustituto, el artículo 4 establecía que estuviese en el ejercicio de sus derechos civiles, vecino del pueblo, saber leer y escribir y tener más de veinticinco años, junto a las exigidas para ser elegido alcalde o teniente de alcalde. Se excluían obligatoriamente a (artículo 5):i) los deudores a los fondos públicos, ya fuesen generales, provinciales o locales, "como segundos contribuyentes"; ii) los que hubiesen hecho suspensión de pagos si haber obtenido la rehabilitación; iii) los procesados criminalmente con autos de prisión y los que estén inhabilitados para ejercer cargos públicos; iv) los que desempeñen oficio o cargo público asalariado en el pueblo donde vayan a ejercer

${ }^{10}$ Sobre la nueva organización judicial surgida tras la publicación de la Ley de Enjuiciamiento civil de 1855, pueden verse: Álvarez CORA, E., La arquitectura de la justicia burguesa. Una introducción al enjuiciamiento civil en el siglo XIX (Madrid, 2002); BARNUEVO, J. M., Deben valerse los jueces municipales de asesor cuando practique algún embargo preventivo, en Revista General de Legislación y Jurisprudencia, 43 (1873); Lasso Gaite, J. F., cit. (n. 1); Lorente Sariñena, M. - Martínez Pérez, F. - Solla Sastre, M. J., cit. (n. 8); Martínez Alcubilla, M., Manual de las atribuciones de los jueces de paz (Madrid, 1859); MAS y ABAD, C., Manual del juez de paz (Madrid, 1857); Montero Aroca, J., cit. (n. 8); Paredes, J., cit. (n. 9); Ortiz de ZúNiga, M.: Práctica general forense (4a edición, Madrid, 1861). 
las funciones de juez paz; v) los ordenados in sacris; vi) los impedidos física y moralmente; y vii) los mayores de ochenta años.

Podría eximirse voluntariamente del cargo de juez de paz los mayores de setenta años y aquellas personas que hubiesen sido reelegidas sin mediar un bienio (artículo 6).

El juez de paz y su suplente sería nombrado en el mes de diciembre cada dos años, y si en el intermedio la plaza resultase vacante, por los regentes de las $\mathrm{Au}$ diencias, entrando en el ejercicio de sus cargo el 1 de enero siguiente. Los suplentes reemplazarían a los propietarios durante las ausencias y enfermedades de éstos (artículo 7). Comenzaría el juez de paz el desempeño de su oficio jurando en el ayuntamiento guardar y hacer guardar la Constitución y las leyes y que ejercería lealmente su cargo (artículo 8). Los servicios prestados por el juez de paz serían considerados como méritos especiales que se tendrían en cuenta por el Gobierno (artículo 14).

Podría el juez de paz nombrar los secretarios y porteros de sus juzgados, siendo estos amovibles a su voluntad (artículo 9); la persona que ocupase el puesto de secretario de juzgado de paz debía ser español, mayor de veinticinco años, saber leer y escribir y tener voto en las elecciones para cargos municipales; el portero, por su parte, solamente se le requería ser mayor de veinte años y saber leer y escribir. Ambos cargos eran voluntarios, excepto en el caso de que nadie los aceptara y el juez de paz quisiese nombrar a los secretarios y alguaciles del municipio (artículo 10). Percibirían los secretarios y los porteros de los juzgados de paz los derechos establecidos en los aranceles vigentes "o los que se establezcan en lo sucesivo para los actos en que funcionan como tales"; los gastos que ocasione el desempeño de la secretaría serán de cuenta del secretario (artículo 11). Los secretarios son responsables de la conservación de los libros donde se asientan los actos de conciliación, de los registros que deba llevar el juzgado y de las actuaciones, correspondencia y otros papeles que le pertenezcan y deban archivarse (artículo 12). Al final del bienio deberán entregar dichos libros en los juzgados de primera instancia, recogiendo un resguardo "sin el cual no podrán eximirse de la responsabilidad declarada en el artículo anterior" (artículo 13).

Finalizaba el Real Decreto en su artículo 15 encargando al Ministerio de Gracia y Justicia que promulgase las disposiciones para realizar cuanto antes el cumplimiento de dicha norma. Dicho mandato se plasmó en la Real Orden de 12 de noviembre de 1855 .

La Real Orden de 12 de noviembre de 1855 establecía las reglas que debían observar los regentes de las Audiencias para nombrar a los jueces de paz. Los regentes se dirigirían a las diputaciones provinciales para que les facilitasen una lista de los vecinos de los pueblos en que existiese ayuntamiento y que tuviesen las cualidades requeridas para ser alcalde " $y$ cuantas noticias estimen que pueden conducir al más acertado nombramiento de los Jueces de paz" (regla 1a). Por otro lado, la regla $2^{\text {a }}$ ordenaba a los jueces de primera instancia que remitiesen a los regentes una nota de las personas avecindadas en los pueblos de su partido que reuniesen las cualidades requeridas para cumplir como jueces de paz, "indicando los que en su concepto merezcan ser nombrados con preferencia”. 
A la vista de todos estos informes, los regentes harían el nombramiento de los jueces de paz y de sus suplentes, comunicándolo a través de los jueces de primera instancia a los interesados y publicándolo en el Boletín Oficial de las respectivas provincias en los primeros quince días del mes de diciembre (regla $3^{\mathrm{a}}$ ). En caso de reclamaciones, bien por falta de cumplimiento de los requisitos exigidos legalmente en la persona de los designados, bien por excusas que los nombrados alegasen, la Audiencia en pleno tendría que resolverlas en los últimos días del mes de diciembre, estimando lo que creyese "justo y conveniente" y su resolución se ejecutará sin ulterior recurso (regla 4 a ). Para evitar dilaciones y perjuicios mientras se tramitan las reclamaciones, las personas nombradas como jueces de paz deberán entrar o continuar en el ejercicio de sus cargos, mientras no se les comunique de manera formal que las reclamaciones han sido estimadas (regla 6 a).

Si hubiesen quedado sin efecto los nombramientos, los harán de nuevo los regentes de las Audiencias, teniendo a mano los informes elaborados anteriormente por las diputaciones y por los jueces de primera instancia (regla $5^{\mathrm{a}}$ ). En el caso de no haberse hecho oportunamente los nombramientos "o por hallarse ausentes, enfermos o por otro motivo justo", no pudiesen los nombrados ejercer su cargo de juez de paz o suplente el 1 de enero, los alcaldes se ocuparían de los juzgados de paz hasta que aquellos lo realicen, haciendo de secretarios y porteros los que lo fuesen de las alcaldías (regla $7 \mathrm{a}$ ).

Sí el Real Decreto de 22 de octubre solamente aludía a las atribuciones de los jueces de paz que les concedía la Ley de Enjuiciamiento civil, la Real Orden en su regla $8^{\mathrm{a}}$ ampliaba sus competencias también a los asuntos penales, al establecer que conocerían "de las faltas de que trata el libro tercero del Código penal”, y practicarían las primeras diligencias de los delitos cometidos en su demarcación, remitiéndoselas a continuación a los jueces de primera instancia. De esta forma se conseguía la definitiva separación en el ámbito municipal de las funciones de justicia y de administración, y así lo recalcaba la regla 9a al establecer que: "No pudiendo los Tribunales ejercer otras funciones que las de juzgar y hacer que se ejecute lo juzgado, no es permitido a los Jueces de paz, mientras lo sean, desempeñar las de ningún otro cargo perteneciente al orden administrativo".

En cuanto al nombramiento de sus auxiliares, los jueces de paz no estaban obligados a nombrar como secretarios a los escribanos numerarios o notarios del pueblo y su término municipal (regla 10a); y cuidarían que los secretarios fijasen en su despacho el arancel conforme al cual percibirían ellos sus derechos y los porteros (regla 11 a).

Ninguna de estas disposiciones, ni las posteriores, aludían al régimen jurídico que debía tener el asesor del juez de paz cuando éste no fuera un experto en Derecho, pues como hemos vistos, la Ley de Enjuiciamiento civil obligaba a su utilización en determinadas actuaciones procesales.

No cabe duda que tanto la nueva Ley de Enjuiciamiento civil, el Real Decreto de 22 de octubre y la Real Orden de 12 de noviembre de 1855 suponían la adecuación definitiva de la justicia municipal al mandato constitucional de la separación de poderes. Sin embargo, a pesar de que los regentes de las Audiencias habían comenzado a realizar los nombramientos de las personas que consideraban capaces 
para el cargo de jueces de paz, la Real Orden de 2 de enero de 1856 los suspendía, alegando que dichos nombramientos habían producido "quejas y reclamaciones, más o menos fundadas, sin duda por la dificultad que siempre ofrecen los primeros ensayos en asuntos de esta consideración, y con especialidad en circunstancias como las presentes; $y$ tratándose de elección de persona en tanto número, en que los delegados del Gobierno han tenido precisión de fiarse de informes cuyos autores han atendido, más que a la conveniencia del principio meramente judicial, a consideraciones políticas, contrariando de todo punto el fin que se propuso el Gobierno de alejar todo roce politico $y$ administrativo del ejercicio de las funciones judiciales". Por ello se ordenaba que se dejasen de enviar informes por parte de las diputaciones provinciales y por los jueces de primera instancia a las Audiencias y todos los nombramientos quedasen en suspenso, retomando las funciones judiciales en el ámbito municipal los alcaldes. La causa principal de esta resolución era más política que técnica, pues el gobierno presidido por el tándem Espartero-O’Donnell no obtuvo nombramientos complacientes y ello le llevó a dictar dicha suspensión.

Suspensión que tuvo corta vida pues el nuevo gobierno, cuya presidencia recaía en Narváez, ordenó mediante el Real Decreto de 28 de noviembre de 1856 la instauración de los juzgados de paz. En la exposición de motivos del Real Decreto se hacía una importante crítica a la medida tomada al decir que "esta providencia gubernativa, que suspendió la ejecución de una ley, no puede continuar en observancia por más tiempo sin privar a los pueblos de las ventajas que ha de producir la conveniente separación entre las atribuciones administrativas y las judiciales, reclamada por los principios del derecho". Sin embargo, sí antes habían sido las diputaciones provinciales y los jueces de primera instancia los encargados de informar sobre los candidatos, el Real Decreto de 28 de noviembre de 1856 establecía que serían ahora los encargados de tal misión los gobernadores civiles de cada provincia, quienes confeccionarían una lista de los abogados domiciliados en los pueblos en que haya ayuntamiento y no estén imposibilitados de realizar dicha función conforme a lo dispuesto en el artículo 5 del Real Decreto de 22 de octubre de 1855 , y otra de aquellas personas que, sin ser abogados, " a su juicio merezcan con preferencia obtener el cargo de Juez de paz en las respectivas poblaciones" (artículo 1. ${ }^{\circ}$ ). Los regentes de las Audiencias, teniendo presentes las listas confeccionadas por los gobernadores civiles, oirán a los jueces de primera instancia sobre las cualidades de los candidatos, teniendo siempre preferencia los abogados en los nombramientos de jueces de paz y de suplentes. Realizados éstos por los regentes de las Audiencias, serán comunicados a los interesados por medio de los jueces de primera instancia para que comiencen a ejercer dichos cargos el 1 de enero del año siguiente, dando cuenta de ello al Ministerio de Gracia y Justicia para su aprobación. En la información remitida al Ministerio se debería añadir las listas realizadas por los gobernadores civiles "con las observaciones que sugieran los informes de los Jueces de primera instancia” (artículo 2). En caso de que el candidato propuesto quisiese eximirse de su cargo, establece el artículo 3 que los regentes, oída a la Sala de Gobierno de su respectiva Audiencia, resolverán rápidamente lo que estimasen más justo sin que quepa ningún recurso contra dicha decisión. Mientras se resuelve la excusa, los candidatos nombrados deberán ejercer 
sus funciones hasta que no se les haga saber formalmente que ha sido estimada (artículo 5); en tal caso, los regentes harían inmediatamente otros nombramientos, teniendo presente las listas referidas anteriormente (artículo 4).

En cuanto a su ámbito territorial, el Real Decreto establece en su artículo 6 que los jueces de paz ejercerán la jurisdicción que les confiere la Ley de Enjuiciamiento civil dentro de la demarcación en que el alcalde ejerce "su autoridady atribuciones gubernativas", no diciendo nada sobre el conocimiento de juicios de faltas tal como se preveía en la regla $8^{a}$ de la Real Orden de 12 de noviembre de 1855. Remarcando la separación de poderes, el artículo 7 ordena que la labor de los jueces de paz, como los otros jueces y tribunales del reino, "es juzgar y hacer que se ejecute lo juzgado" y, por lo tanto, se les prohíbe a sus titulares desempeñar ningún otro cargo perteneciente al orden administrativo.

Cuidarían los jueces de paz de fijar en su despacho el arancel por el que percibirían sus derechos los secretarios y los porteros (artículo 8); sustituirían a los jueces de primera instancia en casos de ausencia, enfermedad o vacante, despachando en esas circunstancia el juzgado de paz las personas que hayan sido nombradas como suplentes (artículo 9). En el caso de haber más de un juzgado de primera instancia en la población, "suplirá a cada uno de ellos el Juez de paz del distrito correspondiente al que es suplido" (artículo 10). Sí hubiese incompatibilidad en el juez de paz para conocer como suplente del juez de primera instancia en los asuntos en los que éste hubiese intervenido, será el suplente quien conocerá de los mismos (artículo 11).

El artículo 12 señala que los titulares de los juzgados de paz y sus suplentes contraerían un mérito especial que sería tenido en cuenta en sus respectivas carreras, "siendo de abono para jubilaciones a los Jueces de paz la mitad del tiempo que ejerzan aquellos". Finalmente, el artículo 13 ordenaba la derogación de los preceptos del Real Decreto de 22 de octubre de 1855 que no estuvieran conformes a las contenidas en esta norma.

La intervención de los gobernadores civiles en el nombramiento de los jueces de paz a través de la formación de listas de candidatos politizó la justicia, causando importantes problemas denunciados por los regentes de las Audiencias, pues los gobernadores tan sólo señalaban un candidato que consideraban idóneo para ocupar la plaza, coartando por ello la libertad de los regentes. Por ello, la Real Orden de 26 de diciembre de 1856 estableció que las listas confeccionadas por los gobernadores al menos debían de tener como mínimo tres personas para cubrir cada una de las plazas, tanto de titulares como de suplentes. Junto a estas listas, la Real Orden concluía que "se dirijan los regentes a los jueces de primera instancia, si lo creen conveniente, pidiéndoles la nota de los que a su juicio merezcan en su distrito obtener los referidos cargos todo con el objeto de que la esfera dentro de la cual se haga la elección, sea la más lata posible para que pueda así responder a los altos fines de la ley y a lo que exige el interés público".

Sin embargo, el cumplimiento de la normativa en el nombramiento de jueces y de suplentes tampoco fue realizado de forma eficaz por los regentes de las $\mathrm{Au}$ diencias, pues, a pesar de la prohibición establecida de nombrar a personas que ocupasen cargos en la Administración, la Real Orden de 9 de febrero de 1857 
informaba del nombramiento como jueces de paz a alcaldes y tenientes de alcaldes "resultando de ello el conflicto de haber quedado reducidas muchas Municipalidades a un número de Concejales insuficiente para el desempeño de sus atribuciones, y privadas a la vez de los que en ellas ejercen las más importantes funciones". Para solucionar este problema, se permitió que continuaran ejerciendo ambos cargos (juez de paz y alcalde/teniente de alcalde) hasta la futura constitución de los ayuntamientos, "habiendo asimismo resuelto $S$. $M$. que sean compatibles y puedan desempeñarse a la vez los cargos de suplentes de jueces de paz y de regidores sindicos".

La Real Orden de 16 de abril de 1857 salía al paso para resolver nuevas dudas planteadas por los regentes de las Audiencias sobre los juzgados de paz. A destacar de esta nueva norma la limitación de la competencia de los jueces de paz al ámbito civil, tal como se dice en el artículo 1: "La jurisdicción que compete a los jueces de paz es únicamente la que les concede la Ley de Enjuiciamiento civil, en cuya consecuencia se abstendrán de conocer en asuntos de materia criminal, por ahora, y mientras otra cosa no se disponga". Completaba los artículo s 9 y $10 \mathrm{del}$ Real Decreto de 28 de noviembre de 1856 al indicar que las suplencias de los jueces de primera instancia serían realizadas por jueces de paz que fuesen abogados, teniendo preferencia el que fuese más antiguo en el ejercicio de la abogacía; en los lugares donde no fuesen abogados, "será suplente el juez de paz primero: según el orden de los nombramientos, y no constando esta circunstancia, el mayor en edad'. No podían ejercer como suplentes de los jueces de primera instancia los que lo fuesen de los de paz (artículo 2). La Real Orden también aclaraba quien era la autoridad judicial encargada de autorizar las ausencias de los jueces de paz de sus localidades: sí ésta no excedía de quince días bastaba con acudir a solicitarla al juez de primera instancia, pero sí el plazo era superior debían de dirigirse a los regentes de las Audiencias (artículo 5). En cuanto a honores, los jueces de paz podrían usar "la misma clase de bastón con borlas que sirve de distintivo a los Alcaldes" (artículo 6); y, finalmente, las órdenes que los regentes de las Audiencias deban comunicar a los jueces de paz se insertarían en los boletines oficiales de las provincias (artículo 7).

Otra Real Orden de 31 de mayo de ese mismo año establecía que quedaban exentos del cargo de juez de paz a los retirados y demás aforados de guerra, "que desde ahora quedará comprendida entre las consignadas en el artículo $6^{\circ}$ del Real Decreto de 22 de octubre de 1855".

Antes de la promulgación de la Ley Orgánica del Poder Judicial de 1870, hay que destacar dos normas que perfilan la institución del juez de paz. En primer lugar, el Real Decreto de 22 de octubre de 1858. Su artículo 1 establecía el número de jueces de paz que debía de haber en cada localidad, declarando que en aquellas donde hubiese juzgados de primera instancia debía de existir la misma cantidad de jueces de paz, mientras que en aquellas donde no hubiese dichos juzgados de primera instancia solo habría un juez de paz. En cuanto a los suplentes, se indicaba que habría dos por cada juzgado de paz. No podrían desempeñar el cargo de juez de paz los subalternos de los juzgados de primera instancia ni los promotores fiscales sustitutos que hubiesen en dichos juzgados (artículo 2). Antes de tomar posesión del cargo, tanto los titulares como los suplentes del juzgado de 
paz debían prestar el juramento "de costumbre", ante el juez de primera instancia del distrito respectivo (artículo 12). En el tema de los honores que debía ostentar el juez de paz, el Real Decreto reproducía en su artículo 15 lo dispuesto en la Real Orden de 16 de abril de 1857, así como el artículo 16 copiaba literalmente lo establecido en el artículo 12 del el Real Decreto de 28 de noviembre de 1856 en lo referente a la consideración de méritos y servicios desempeñados por los jueces de paz y sus suplentes.

En cuanto a las competencias de los jueces de paz, se ordenaba en el artículo 3 que éstas se concretaban en los juicios de conciliación y en los verbales, valiéndose en sus juzgados de sus secretarios; en las demás diligencias y actos judiciales que de acuerdo a la ley deleguen en ellos los jueces de primera instancia se valdrían de escribano siempre que legalmente se exija; si no hubiese escribano en el pueblo, "autorizarán las propias diligencias los secretarios, haciendo constar aquella circunstancia".

Las poblaciones con más de un juzgado de primera instancia y, por ende, con más de un juzgado de paz, tendrían éstos asignado un distrito para ejercer su jurisdicción, siendo sus resoluciones susceptibles de apelación ante el juez de primera instancia de dicho distrito (artículo 4). En las ausencias, enfermedades o vacantes de los jueces de primera instancia de cabeza de partido el juez de paz les sustituiría; en los casos donde hubiere más de un juez de primera instancia, "cada juez de paz suplirá al de su distrito" (artículo 5).

El tema de la preferencia de letrados en el ejercicio de las funciones judiciales se manifiesta en el artículo 6 al determinarse que, sí el juez de paz se encuentra incapacitado para suplir al juez de primera instancia, uno de los suplentes "ejercerá la jurisdicción ordinaria, prefiriéndose siempre el que sea abogado; y si los dos lo fueren, el más antiguo en la profesión"; sí ambos suplentes no fueran letrados, ejercería la jurisdicción el designado en primer lugar. Sí la incapacidad del juez de paz tuviese lugar en los pueblos con más de uno de ellos, el artículo 7 establece una regla de llamamientos por el siguiente orden: $1^{\circ}$ Los demás jueces de paz que sean letrados, prefiriendo el más antiguo en la profesión, si hubiere varios; $2^{\circ}$ Los suplentes que sean letrados, en la misma forma; $3^{\circ}$ Los jueces de paz no letrados, según su denominación numérica; y $4^{\circ}$ Los suplentes no letrados, empezando por los del juez a quien ha de sustituirse, según el mismo orden numérico.

En el caso de fallar las previsiones previstas en los dos artículo $s$ anteriores, el juez de primera instancia sería sustituido por los alcaldes y tenientes de alcalde "por su orden”, prefiriéndose a los letrados (artículo 8). Sin embargo, la decisión final correría a manos de las Salas de gobierno de las Audiencias, pudiendo nombrar un juez en comisión "cuando lo crean conveniente al mejor servicio", informando de ello al Ministro de Gracia y Justicia (artículo 9).

Sí el juez de paz demandase a uno de sus suplentes, o viceversa, y no hubiese otro juez de paz en aquel lugar, el artículo 10 establece que será encargado de resolver el conflicto el otro suplente y, en su defecto, el alcalde y los tenientes del mismo; en los lugares donde hubiese más de un juez de paz, el demandante se dirigiría al más antiguo, según el orden numérico, después a los suplentes en igual forma y, por último, a los alcaldes y sus tenientes. 
El Real Decreto de 22 de octubre de 1858 acogía en su artículo 11 la solución prevista en la Real Orden de 16 de abril de 1857 sobre las ausencias de los jueces de paz del lugar donde ejercen su jurisdicción: si la ausencia es inferior a quince días debía ser solicitado el permiso al juez de paz; sí era superior a ese término, el regente de la Audiencia era el encargado de resolver. Añadía el Real Decreto que "en caso de urgencia, los jueces de paz podrán ausentarse por ocho dias sin previa licencia, dando aviso en el de su salida al juez de primera instancia respectivo". En caso de incumplirse lo previsto en este artículo, se establecía una sanción disciplinaria a los titulares de los juzgados de paz de 40 a 200 reales, "según los casos y circunstancias".

En cuanto a las calidades que debía ostentar la persona que ocupase la secretaría del juzgado de paz bastaba que tuviera 25 años, supiese leer y escribir y estar en posesión de sus derechos de ciudadanía, además de haber concluido la carrera notarial, conforme a lo previsto en la Real Orden de 21 de octubre de 1858 (artículo 13) ${ }^{11}$. Los nombramientos serían comunicados por los jueces de paz a los de primera instancia, observándose el mismo requisito en el caso de que el secretario del juzgado de paz fuera removido (artículo 14).

Por último, finalizaba el Real Decreto en su artículo 17 derogando todas aquellas disposiciones que fuesen contrarias a lo establecido en él.

Como complemento de este Real Decreto, el 20 de noviembre se promulgaba una Real Orden, en la que, coincidiendo con el período de renovación de los titulares y suplentes de los juzgados de paz, se volvía a reiterar la prohibición de elegir para dichos cargos a personas que ocupasen los puestos de alcaldes y tenientes de alcaldes en los pueblos y, en el caso del juramento, se autorizaba a los regentes que pudieran permitir a los jueces de paz de pueblos que durante el invierno estuviesen incomunicados y que no fuesen cabeza de partido que pudiesen hacerlo en el ayuntamiento, remitiéndolo después al juzgado de primera instancia, pues así "se respeta el principio de dependencia en que debe estar el inferior de su superior, que en este caso delega sus facultades; y se consulta también la comodidad de los jueces de paz que al cabo prestan un servicio gratuito".

La otra norma a destacar antes de la Ley Orgánica del Poder Judicial de 1870 es el Real Decreto de 14 de octubre de 1864 . En dicha norma se establecían importantes modificaciones en el estatuto de los jueces de paz y de sus suplentes. En primer lugar, la duración de su cargo, que pasaría de dos a cuatro años (artículo 1) y, que no podrían ser separados por los regentes de las Audiencias sino en virtud de expediente formulado por el regente oído el parecer de la Sala de gobierno, "dando cuenta siempre al Ministerio de Gracia y Justicia" (artículo 5); el nombramiento de los secretarios de los juzgados de paz sería realizado por los jueces de primera instancia, proponiendo los candidatos el juez de paz; los secretarios no

${ }^{11}$ El artículo 1 de la Real Orden de 21 de octubre de 1858 disponía lo siguiente: "Las procuras del Tribunal Supremo, las de Audiencias territoriales y las de Juzgados de primera instancia que sean propiedad del Estado; las Notarias y Escribanias eclesiásticas, de guerra, de marina, de hacienda y de comercio que necesitan cédula de notaría parcial, según la Real Orden de 28 de febrero de 1856, y las Secretarias de los Juzgados de paz, se proveerán en personas que tengan concluida la carrera del notariado". 
podrían ser separados sin previa formación de expediente por el juez de primera instancia y oyendo al juez de paz y al interesado (artículo 3). La presentación de candidatos para la secretaría del juzgado de paz se realizaría en el plazo de un mes contado desde la fecha que hubiera tomado posesión el titular de dicho juzgado; sí se dejase transcurrir dicho plazo continuaría en sus funciones el secretario que en ese momento lo fuera (artículo 4).

Pocos meses antes de la Revolución de Septiembre de 1868, el 23 de enero de ese año se publicó una Real Orden que modificaba parte de la regulación del cuerpo de secretarios de paz, estableciendo como requisitos, además de ser español, mayor de 25 años, de estado seglar y de buena conducta, se necesitaba "reunir, indistintamente, el carácter de Abogado, Notario o Escribano, o de haber concluido la carrera del Notariado, según la actual o las anteriores legislaciones" (artículo 1). Si la secretaría del juzgado de paz no fuere solicitada por ninguna persona que reuniese esas cualidades especiales, podrían ser propuestos, los que reúnan "la de ser Procuradores, haber practicado en Escribanía o procura por un año a lo menos, desempeñado por cualquier tiempo Secretarías de Juzgados de paz, o estar incluidos en las listas de electores de Ayuntamiento y saber leer y escribir" (artículo 2). Todos los candidatos propuestos al cargo de secretario de juzgado de paz, tanto los que hubiesen concluido la carrera del Notariado como los que no, deberían realizar un examen de idoneidad ante el juez de primera instancia antes que les diese posesión de dicho cargo (artículo 3); el juez de paz, por su parte, remitiría al juez de primera instancia en el plazo previsto en el Real Decreto de 14 de octubre de 1864 los documentos que justifique la aptitud legal del candidato propuesto, $y$ el juez de primera instancia dará cuenta al regente de la Audiencia en el plazo de ocho días del nombramiento y de las condiciones del nombrado (artículo 4).

El cargo de secretario de juzgado de paz sería permanente y para ser removido de él se tendría que formar expediente justificando las causas de remoción, remitiendo un extracto del mismo el juez de primera instancia al regente de la Audiencia (artículo 5). Se ratificaba también en el artículo 6 las incompatibilidades del cargo de secretario de juzgado de paz con el ejercicio de la abogacía, notariado, escribanía y procuraduría, así como "con todo empleo, destino o comisión que tenga sueldo consignado en el presupuesto general del Estado y en los provinciales o municipales, y con todo otro de elección popular". Solamente era compatible con el ejercicio de la secretaría del ayuntamiento, lo cual nos dice que era en la mayoría de los casos la misma persona ocupaba ambos cargos. Por último se ordenaba que en el mes de enero se hiciesen los nombramientos de los secretarios de juzgados municipales, pudiendo continuar los actuales, sujetos a las incompatibilidades previstas, sí lo jueces de paz no propusieran otros en el plazo de un mes desde que éstos tomasen posesión de su cargo, tal como se dispuso en el Real Decreto de 14 de octubre de 1864 (artículo 7).

Con la Real Orden de 23 de enero de 1868 se cierra el ciclo de reformas de la época de Isabel II que inciden en la justicia municipal. Sin embargo, poco tiempo después, como hemos adelantado, la justicia municipal se vería inmersa en otras nuevas con motivo de la Revolución de 1868. 


\section{LA CREACIÓN DE LOS JUZGADOS DE PAZ EN ULTRAMAR ${ }^{12}$}

La Real Cédula de 30 de enero de 1855 había ordenado que en Cuba y en Puerto Rico fueran los alcaldes ordinarios y los capitanes de partido de Cuba quienes ejercieran la jurisdicción a nivel local. Conforme al artículo 2 de dicha Real Cédula, estaban encargados de la labor de conciliación y llevar a efecto lo convenido; conocer de las demandas verbales civiles cuya cuantía no fuese superior a 200 pesos fuertes y de las penales de injurias y faltas livianas ${ }^{13}$; admitir toda clase de informaciones que se les solicitase pertenecientes a la jurisdicción voluntaria hasta el auto de aprobación inclusive, que debe dictarse por juez letrado; proceder de oficio o a instancia de parte a formar las primeras diligencias del sumario, siempre que en su distrito municipal se cometa algún delito o se encuentre algún delincuente; $y$, sustituir donde no haya gobernador o teniente a los jueces de partido que residan en el mismo pueblo, durante sus ausencias, enfermedades y casos de inhabilitación, así como en las vacantes, a no ser que el presidente de la Audiencia disponga o hubiese dispuesto otra cosa. Sí alguno de los tenientes de alcalde donde los haya fuese letrado, siempre será preferido al alcalde y a los primeros tenientes legos para sustituir al juez. A falta de tenientes, correspondía la sustitución a los individuos del ayuntamiento letrados y los demás por su orden.

La tardía aplicación de la Ley de Enjuiciamiento civil de 1855 diez años más tarde en las provincias de Ultramar llevó consigo la aparición en dichos territorios de los juzgados de paz. El Real Decreto de 9 de diciembre de 1865, firmado por el ministro de Ultramar D. Antonio Cánovas del Castillo, estableció las bases fundamentales por las cuales, además de aplicar la nueva Ley de Enjuiciamiento civil, se reformó la administración de justicia en dichos territorios.

En él se establecía como cuantía máxima de los juicios verbales la cantidad de 400 escudos (artículo 2), en vez de los 600 reales dispuestos en el artículo 1162 de la Ley de Enjuiciamiento civil. Pero, aparte de esta norma más importancia tiene una Real Orden de igual fecha dirigida a los gobernadores civiles y a los regentes de las Audiencias de Cuba y Puerto Rico por la cual se creaban en esas islas la figura del juez de paz.

A imitación de la normativa para la metrópoli, habría jueces de paz en cada pueblo que tuviere ayuntamiento o junta municipal, "con las atribuciones que se determinan en la Ley de Enjuiciamiento civil”, cuyo número vendría determinado por la existencia en el pueblo de alcaldes mayores, siendo en este caso igual a éstos,

${ }^{12}$ Sobre la creación de la nueva justicia municipal en Cuba y Puerto Rico: CésPEDES Y Orellano, J. M., Elementos teórico-prácticos de procedimientos civiles con aplicación a la isla de Cuba (La Habana, 1862), I; Martínez Alcubilla, M., Diccionario de la Administración española, peninsular y ultramarina (2a edición, Madrid, 1869), VIII.

${ }^{13}$ Conforme con el artículo 2 del Reglamento para los juicios verbales de Cuba y Puerto Rico de 21 de febrero de 1853 se disponía que: "Serán Jueces de estas demandas:/ 10 Los Capitanes jueces pedáneos de Cuba respecto de las personas domiciliadas en su partido, no excediendo de 30 pesos lo cuestionado; $2^{\circ}$ Los Alcaldes ordinarios de los pueblos donde haya Alcalde mayor a prevención con estos y con los Gobernadores y tenientes de Gobernador no pasando la demanda de cincuenta pesos, respecto de las personas de su mismo pueblo". 
o sólo uno si no hubiera ningún alcalde mayor (artículo 1). En lo demás, la Real Orden reproducía de una forma más coherente la normativa que se aplicaba en España sobre los juzgados de paz, que como hemos visto se encontraba dispersa en varias normas. Diferencias especiales eran: $i$ ) la duración del mandato, que era de dos años (artículo 2), en vez de los cuatro años que había introducido el Real Decreto de 11 de octubre de 1864; ii) disminuye la edad como causa exención forzosa (mayor de 70 años) o voluntaria (mayor de 60 años) para ocupar los cargos de juez de paz y de suplente del mismo (artículo s 4 y 5); iii) si el juez de paz letrado sustituyera al alcalde mayor por más de un mes, percibiría “el sueldo señalado a la Alcaldía mayor, sino lo disfrutare el propietario, o la mitad, si éste lo cobrare”. Sí no fuese letrado, percibiría los derechos de arancel (artículo 19); y iv) los jueces de paz nombraban a los secretarios y porteros de sus juzgados (artículo 24), competencia que en España por el Real Decreto antes mencionado correspondía a los jueces de primera instancia.

Los juzgados de paz, con sus vicisitudes debido a que muy pronto iba a estallar la rebelión cubana tras el "Grito de Yara" en octubre de 1868, se instalaron de la forma indicada en las provincias de Ultramar.

\section{LAS REFORMAS EN LA JUSTICIA MUNICIPAL TRAS LA REVOLUCIÓN DE $1868^{14}$}

La revolución de septiembre de 1868 trajo consigo modificaciones legislativas muy importantes en la organización política de la época, especialmente en el ámbito judicial. En lo que atañe a la justicia municipal, la primera decisión que tomó el gobierno provisional fue el cambio en la forma de designar a los jueces municipales mediante la promulgación del Decreto de 7 de noviembre de 1868 . En su exposición de motivos, el ministro de Gracia y Justicia Antonio Romero Ortiz denunciaba la politización a que había estado sometida la justicia municipal y declaraba que "la indole de las atribuciones que la Ley de Enjuiciamiento civil vigente ha confiado a los Jueces de Paz, reclama condiciones de equidad y de justicia, de prestigio y autoridad, que en los últimos tiempos no siempre se tuvieron presentes, resistiéndose a veces sus nombramientos del espiritu de parcialidad y exclusivismo, que en este como en todos los ramos, marcaba la senda de retroceso por donde venía impelida la pública Administración [...]. Expresión del alzamiento que la puso término, el ministro que suscribe no puede que mirar con indiferencia este gravisimo asunto, ni consentir la continuación de funcionarios cuyos nombramiento, más que de la iniciativa espontánea de los regentes de las Audiencias, a quienes la ley confía tan importante misión, han sido debidos a imposiciones ejercidas en provecho de una politica intolerante. Y como a la gravedad del mal corresponde la urgencia del remedio, no es posible esperar a la época en que naturalmente debiera tener lugar la renovación de aquellos funcionarios".

Por ello se acordaba la renovación de todos los juzgados de paz en toda la

${ }^{14}$ Sobre este tema: Abella, F., Manual del Registro civil (5a edición, Madrid, 1885); Álvarez Cora, E., cit. (n. 10); Lasso Gaite, J. F., cit. (n. 1); Lorente Sariñena, M. - Martínez Pérez, F. - Solla Sastre, M. J., cit. (n. 8); Montero Aroca, J., cit. (n. 8): Paredes, J., cit. (n. 9); SAINZ Guerra, J., cit. (n. 1). 
Nación y en las islas adyacentes (artículo 1), enviando los gobernadores y los jueces de primera instancia a los regentes de las Audiencias antes del 25 de noviembre de dicho año listas de las personas que tuviesen las cualidades requeridas para desempeñar el cargo de juez de paz (obviamente, aunque se criticaba la politización, una de las cualidades, aunque no se dijera, sería que fuera fiel a la Revolución de Septiembre) (artículo 2). Los regentes designarían al candidato, quien tomaría posesión el 1 de diciembre (artículo 3). De forma provisional, los actuales jueces de paz seguirían en sus cargos hasta que fuesen relevados (artículo 4).

Con la unificación de fueros llevada a cabo por el Decreto de 6 de diciembre de 1868, se abría un campo de actuación a los jueces de paz. La supresión de la jurisdicción de comercio hizo que las antiguas competencias de los tribunales de este ramo pasaran a cargo de los jueces de primera instancia, pero, aparte de las conciliaciones y los pleitos verbales mercantiles, que habían sido competencia de los jueces de paz de aquellos lugares donde no hubiera un órgano judicial mercantil (artículo 1210 del Código de Comercio de 1829), los jueces municipales podían practicar diligencias de esta materia, siempre y cuando en la localidad no fuera cabeza de partido y, por tanto, no hubiese juez de primera instancia, "cuando la urgencia del negocio o la circunstancia de existir alli los medios de prueba o los efectos mercantiles lo requieran previa declaración especial de los mismos Jueces, fundada en cualquiera de dichas circunstancias" (artículo 17 del Decreto de 6 de diciembre de 1868). Las diligencias practicadas deberán ser remitidas al juez de primera instancia, mandándolas éste protocolizar (artículo 18).

A las competencias de naturaleza mercantil que les había añadido el Decreto de unificación de fueros, la Ley de Matrimonio civil de 18 de junio de 1870 les encargaba la celebración de este tipo de matrimonios, aunque en ella se hablase de "juez municipal”, pues el Decreto de 16 de agosto de 1870 en su disposición transitoria $1^{\mathrm{a}}$ aclaraba que las alusiones al juez municipal debían referirse al juez de paz. Conforme con los artículos 9 y 10, ante el juez de paz de su domicilio o del de uno de ellos, debían los contrayentes manifestar por escrito su decisión, con los datos requeridos por la ley (nombre, apellidos, edad, profesión, oficio, provincia y lugar de nacimiento, y su residencia durante los últimos dos años). El juez de paz mandaría fijar edictos en el local de su audiencia pública y en un sitio público de la parroquia del último domicilio de los interesados y remitirá también edictos a los jueces municipales del territorio donde hubieren residido o estado domiciliados los contrayentes en los últimos dos años para que los fijen en sus respectivas audiencias o en un lugar público (artículos 11 y 12). Los edictos se fijarán dos veces consecutivas por el término de ocho días cada uno (artículo 13).

Podrá el juez de paz dispensar la publicación de los edictos en el caso de que uno de los interesados se hallase en inminente peligro de muerte (artículo 16); en este caso, el artículo 43del Reglamento del registro civil de 13 de diciembre de 1870 ordena al juez que exija un certificado facultativo donde se exprese esta circunstancia antes de tomar una decisión y, en vista de ella y de los demás informes que sobre el caso pueda adquirir, acordará la dispensa si lo considera suficientemente justificado el peligro inminente de muerte. Cuando los edictos hubiesen sido publicados por otros jueces municipales que no fueran el que tuviese 
que autorizar el matrimonio, podrán expedir a instancia de los interesados, a los cinco días de concluir el plazo de la publicación de los edictos, certificación de los impedimentos que se les hubieren denunciado, o negativa en el caso de que no exista denuncia alguna (artículo 19).

También el juez de paz es competente para conocer las oposiciones a la celebración del matrimonio que se presenten en el plazo de cinco días tras la publicación de los edictos alegando los impedimentos legales que padecen uno o los dos contrayentes (artículo s 20 y 23). Sí la denuncia fuese por escrito, el juez municipal acordará que el denunciante se ratifique en ella el denunciante en el plazo de veinticuatro horas; sí fuese verbal, se hará constar en acta, que autorizará el secretario del juzgado de paz y firmará el denunciante si supiese firmar (artículo 25). Hecha la ratificación, el artículo 48, $3^{\text {a }}$ del Reglamento del registro civil establece que el juez dictará providencia mandando notificar la denuncia a los futuros contrayentes y a sus padres o curadores, si aquellos fueren menores de veinticinco años.

En cuanto a la tramitación de la denuncia, el artículo 26 declara que esta se sustanciará conforme al procedimiento establecido en la Ley de Enjuiciamiento civil (artículo 26). Sin embargo, primero el Decreto de 16 de agosto de 1870 y después el Reglamento del registro civil, establecieron el procedimiento a seguir en este caso. Sí la denuncia privada fuese declarada maliciosa por sentencia firme, se condenará al denunciante a la indemnización de los daños y perjuicios causados a los interesados (artículo 27).

En cuanto a la celebración del matrimonio, éste se celebrará ante el juez municipal competente y con dos testigos mayores de edad (artículo 28). Se consideraba juez competente el del domicilio residencia de los contrayentes o de cualquiera de ellos, a elección de los mismos (artículo 29). También es competente para autorizar el matrimonio el juez municipal del lugar en donde se encuentre el transeúnte que se encuentre en inminente peligro de muerte (artículo 30).

No se autorizaría la celebración del matrimonio, en caso de haberse hecho denuncia de impedimento legal, hasta que no fuese desechada, y, por regla general, hasta que no fuesen entregados en la secretaría del juzgado los documentos legalmente exigidos (artículo 31). El Reglamento del registro civil ordena al juez municipal en su artículo 51 que examine dichos documentos para cerciorarse de su validez y autenticidad. Solamente se podrá autorizar el matrimonio sin la entrega de los documentos exigidos cuando uno de los contrayentes se encuentre en peligro de muerte inminente (artículo 32).

El Decreto de 16 de agosto de 1870 establecía en su artículo 8, que luego fue recogido en el artículo 54 del Reglamento del registro civil, que el juez municipal no podría delegar sus facultades para la autorización de matrimonios y que en casos de ausencia, enfermedad u otro impedimento legítimo será sustituido por los suplentes.

El matrimonio se celebrará en el local de la audiencia pública del juez que lo autorizase, a no ser que se acordase otra cosa a instancia de los contrayentes, por no poder asistir alguno de ellos al lugar mencionado o por otra causa (artículo 
$37)^{15}$. El artículo 38 recoge la forma de la celebración ${ }^{16}$, que se consignará inmediatamente en un acta, firmada por el juez, los cónyuges y los testigos, si supieren escribir o pudiesen firmar, autorizándola el secretario del juzgado (art 39). El acta se inscribirá, conforme al artículo 66 de la Ley de registro civil de 17 de junio de 1870 , en los libros de la sección de matrimonios de dicho Registro.

De igual fecha que la Ley de matrimonio civil es la Ley del registro civil, cuyo artículo 1 ordena, que sean los jueces municipales, junto con la Dirección General de los Registros Civil y de la Propiedad y del Notariado, y los agentes diplomáticos y consulares españoles en el extranjero, los encargados de llevar un registro en el que inscribirán o anotarán los actos concernientes al estado civil de las personas. El citado Decreto de 16 de agosto de 1870, como en el caso anterior, establecía que las alusiones a juez municipal contenidas en la Ley del registro civil deben ser tenidas como referencias al juez de paz.

El juez municipal estaría asistido en esta función por los secretarios del juzgado (artículo 1, 20 del Reglamento del registro civil de 1870). No podría delegar sus funciones en otro y, en los casos de ausencia, enfermedad u otro impedimento legal, serían sus sustitutos los encargados de realizar dichas funciones (artículo 4 del Reglamento de registro civil de 1870).

El artículo 3 de la Ley del registro civil de 1870 contenía los actos que debían ser inscritos en el Registro Civil encomendado a los jueces municipales: los nacimientos ocurridos en territorio español: los ocurridos en viaje por mar o en el extranjero, si los padres o alguno de ellos tuviesen domicilio conocido en España; los matrimonios que se celebren en el territorio español; los celebrados in articulo mortis en viaje por mar, si alguno de los contrayentes tuviese domicilio conocido en España; los celebrados en el mismo caso por militares en campaña en el extranjero, si fuese conocido su último domicilio en España; los matrimonios celebrados en el extranjero por un español y un extranjero, o por dos españoles, si tienen domicilio conocido en España; los matrimonios de extranjeros, celebrados según las leyes de su país, cuando los contrayentes trasladen a España su

${ }^{15} \mathrm{El}$ artículo 55 del Reglamento del registro civil de 1870 ordena lo siguiente: "El acto de la celebración del matrimonio se verificará con sujeción a las prescripciones de los artículos 37 y 38 de la ley, y además se observarán las siguientes:/ $1^{\text {a }}$ El acto se verificará en el día que los contrayentes designen, poniéndose al efecto de acuerdo con el Juez municipal, y en la hora que éste determine. Todos los días y horas serán hábiles para la celebración del matrimonio; 2a Los dos testigos, que necesariamente lo han de presenciar, serán designados por los contrayentes, debiendo aquellos ser mayores de edad, conforme al artículo 38 de la ley; $3^{a}$ Llegada la hora designada para la celebración del matrimonio, y hallándose presentes los que deban concurrir al acto, el Juez municipal manifestará el objeto de la reunión, y mandará que se proceda a llenar sucesivamente todas las formalidades expresadas en el artículo 38".

${ }^{16}$ Artículo 38 de la Ley de matrimonio civil de 1870: "El matrimonio se celebrará con asistencia de dos testigos mayores de edad, en la siguiente forma:/Primeramente el Secretario del Juzgado leerá los artículo s $1 .^{\circ}, 2 .^{\circ}, 4 .^{\circ}, 5 .^{\circ}$ y $6 .^{\circ}$ de esta ley./ A continuo, y sucesivamente, el Juez interrogará a cada uno de los esposos con la siguiente fórmula: -¿Queréis por esposa (o esposo) a [...]? (El nombre y apellido del contrayente no interrogado.)./ Los contrayentes contestarán por su orden: -Sí quiero.Incontinenti el Juez pronunciará las siguientes palabras: -Quedáis unidos en matrimonio perpetuo e indisoluble; y se terminará el acto de la celebración, leyendo el Secretario del Juzgado los artículo s del capitulo $V$, sección $1^{a}$ de esta ley". 
domicilio; las ejecutorias en que se declare la nulidad del matrimonio o se decrete el divorcio de los cónyuges; las defunciones que ocurran en territorio español; las de militares en campaña, cuando sea conocido su domicilio; las que ocurran en viaje por mar, si el difunto tuviese domicilio conocido en España; las cartas de naturaleza, cuando los interesados elijan domicilio en territorio español; las justificaciones hechas en forma legal por extranjeros que hayan ganado vecindad en territorio de España relativamente a este hecho; las declaraciones de opción por la nacionalidad española, hechas por los nacidos en España de padres extranjeros, o de padre extranjero y madre española; las declaraciones de opción por la nacionalidad española, hechas por los nacidos en territorio extranjero de padre o madre española, si al hacerlas eligiesen domicilio en España; las de españoles que hubiesen perdido esta cualidad, manifestando que quieren recuperarla, si al hacer la declaración eligiesen domicilio en España; las que para recuperar la nacionalidad española hagan las personas nacidas en el extranjero de padre o madre españoles que hubiesen perdido esta cualidad, si al hacerlas eligiesen domicilio en España; las hechas con el mismo objeto por españolas casadas con extranjeros, después del fallecimiento de sus maridos, en el mismo caso que los cuatro últimos supuestos; las que hagan los extranjeros manifestando querer fijar su domicilio en territorio español, o querer trasladarlo a punto distinto dentro del mismo; y las ejecutorias en que se disponga la rectificación de cualquier partida de dichos registros municipales.

Los jueces municipales, como encargados del Registro Civil, debían (artículo 5 del Reglamento del registro civil): recibir todas las declaraciones, solicitudes y documentos que se les hagan o presenten, concernientes al estado civil de las personas; redactar o disponer que se redacten bajo su dirección, las inscripciones, anotaciones y demás asientos que deban extenderse en el Registro; cuidar de la custodia y conservación de los libros del Registro y de todos los documentos que al mismo se refieran; expedir certificación de las actas de inscripción, asientos y documentos que consten en el Registro, y negativas de las que se soliciten y no resulten del mismo; y desempeñar las demás funciones, deberes y atribuciones que, con arreglo a las disposiciones legales, les correspondan.

En su función como encargado del Registro Civil, el juez municipal estaba sometido a las disposiciones dictadas por el Ministerio de Gracia y Justicia y por la Dirección general del ramo (artículo 7 del Reglamento del registro civil de 1870). También se encontrarían bajo la constante inspección del "Presidente del Tribunal del partido respectivo" 17 , sin perjuicio de las inspecciones extraordinarias que conforme a la ley orgánica del poder judicial pudiesen ordenar los presidentes del Tribunal Supremo y de las Audiencias (artículo 8 del Reglamento del registro civil).

${ }^{17}$ La disposición transitoria $11^{\text {a }}$ del Reglamento del registro civil ordenaba que "mientras no se establezcan los Tribunales de partido con arreglo a la ley orgánica del poder judicial, los Jueces de primera instancia desempeñarán en el territorio de su Juzgado respectivo todas las funciones, deberes y atribuciones que se confieren a dichos Tribunales y a sus Presidentes por las leyes de Matrimonio y Registro civil. Los Promotores fiscales y los Secretarios de gobierno de los Juzgados entenderán del mismo modo en los actos correspondientes a los Fiscales y Secretarios del Tribunal de partido". 
Excede de los objetivos de este trabajo el funcionamiento del Registro Civil en manos de los jueces municipales. Sin embargo, ya en el siglo XIX se criticó dejar dicho cometido en los jueces de paz.

\section{LA “LEY ORGÁNICA DEL PODER JUDICIAL” DE $1870^{18}$}

El 15 de septiembre de 1870 se promulgaba por las Cortes la Ley Provisional sobre organización del Poder Judicial, norma, que con algunas variaciones, permaneció vigente hasta 1985. Con dicha norma, el Gobierno provisional surgido de la Revolución de 1868 desvinculó definitivamente la justicia municipal de los municipios y la convirtió en el último grado de la justicia estatal. Hay que tener en cuenta que, como en los casos de la Ley del matrimonio civil y de la Ley del registro civil, la Ley Orgánica del Poder Judicial habla de jueces municipales, pero, el 30 septiembre el Ministerio de Gracia y Justicia publicó una Circular estableciendo en su disposición $4^{\mathrm{a}}$ que "los Jueces de paz deben ejercer las atribuciones que en la ley referida se declaran propias de los Jueces municipales, cuyo nombre también deben usar" ${ }^{\prime 1}$.

El artículo 12 de la Ley Orgánica del Poder Judicial ordenaba la existencia de uno o más jueces municipales en cada término municipal. El juzgado municipal tomaría el nombre del pueblo donde radicase (artículo 15); si hubiese más de uno en aquel lugar, entonces "tomarán el nombre que se dé al cuartel, circunscripción o partido en que ejerzan su jurisdicción, además del de la población en que residan” (artículo 16). El titular del juzgado tenía la obligación de residir en el pueblo donde ejerciese sus funciones (artículo 20); además, si se diesen circunstancias extraordinarias en la población donde no pudiesen ejercer su jurisdicción, como estar sitiada o hallarse ocupada por enemigos o dominada por rebeldes (hay que tener en cuenta que, después de la deposición de Isabel II, los partidarios del carlismo no reconocieron ni al Gobierno provisional ni a Amadeo de Saboya, iniciando a los pocos años la III guerra carlista, de ahí el contenido del precepto) los jueces municipales no están obligados a salir del término municipal como los otros jueces, siendo por ello acreedores "a recompensa si continuando en el ejercicio de su jurisdicción y limitándose a ella contribuyen al orden y a disminuir las consecuencias de las circunstancias anormales en que se encontraren los pueblos" (artículo 22).

La Ley Orgánica del Poder Judicial de 1870 volvía al sistema bienal de duración del cargo de juez municipal, siendo su ocupación obligatoria (artículo 31). Las condiciones legales exigidas para ocupar el cargo eran las comunes para otros cargos judiciales dispuestas en el capítulo $2^{\circ}$ del título $2^{\circ}$ de la Ley (artículos 109 a 115$)^{20}$; aunque se especificaba en el artículo 121 que supieran leer y escribir y

\footnotetext{
${ }^{18}$ Para el estudio de este apartado véase la nota 14 .

${ }^{19}$ Lo mismo sucede, como vemos en la nota anterior, con los Tribunales de Partido, pues la Circular ordena en su disposición $3^{\text {a }}$ que: "corresponden a los Jueces de primera instancia las atribuciones que en la ley orgánica se asignan a los Tribunales de partido o sus Presidentes, o a cualquiera de los Jueces que los han de componer". Por eso, en el texto sustituimos las referencias a estos organismos por la de jueces o juzgados de primera instancia, según los casos.

${ }^{20}$ Artículo 109: "Para ser Juez o Magistrado, cualquiera que sea la clase o denominación del
} 
que estuvieren domiciliados en el pueblo donde hubiesen de ejercer su misión. También se preferirían letrados para ser jueces municipales frente a los que no lo fueren, "a no mediar motivos que aconsejen lo contrario" (artículo 122).

Podían excusarse, conforme al artículo 32, los mayores de sesenta años, los senadores y diputados a Cortes, los que hubiesen sido reelegidos antes de expirar los cuatro años siguientes a aquel en que hubieren cesado en su anterior cargo, y los suplentes de jueces municipales durante los dos años siguientes a aquel en que dejaron de serlo. Percibirían por su labor los honorarios que le señalasen los aranceles judiciales (artículo 212), y usarían como símbolo en todos los actos que ejerciesen jurisdicción o en que concurran como tales una medalla de plata pendiente de un cordón negro (artículo 206), dejando así de llevar los atributos que hasta entonces eran propios de las autoridades municipales.

Junto al titular del juzgado municipal habría un juez suplente, reemplazándole en los casos de vacante, enfermedad, ausencia, incompatibilidad, recusación " $o$ de cualquier otro impedimento legítimo del propietario" (artículo 65), haciéndole

cargo se requiere:/ 10 Ser español, de estado seglar. 20 Haber cumplido veinticinco años./ 3० No hallarse comprendido en ninguno de los casos de incapacidad o de incompatibilidad que establece esta ley./ $4^{\circ}$ Estar dentro de las condiciones que para cada clase de cargos se hallan establecidas en la misma”. Artículo 110: "No podrán ser nombrados ni Jueces ni Magistrados:/ 10 Los impedidos física o intelectualmente. $/ 2^{\circ}$ Los que estuvieren procesados por cualquier delito./ $3^{\circ}$ Los que estuvieren condenados a cualquier pena correccional o aflictiva, mientras no la hayan sufrido u obtenido de ella indulto total./ $4^{\circ}$ Los que hubieren sufrido y cumplido cualquiera pena que los haga desmerecer en el concepto público./ $5^{\circ}$ Los que hubieren sido absueltos de la instancia en la causa criminal, mientras que por el transcurso del tiempo la absolución no se hubiere convertido en libre./ 6o Los quebrados no rehabilitados. $17^{\circ}$ Los concursados mientras no sean declarados inculpables./ $8^{\circ}$ Los deudores a fondos públicos como segundos contribuyentes./ 9o Los que tuvieren vicios vergonzosos./ $10^{\circ}$ Los que hubieren ejecutado actos u omisiones que, aunque no penables, los hagan desmerecer en el concepto público". Artículo 111: "Los cargos de Jueces y Magistrados serán incompatibles:/ 10 Con el ejercicio de cualquiera otra jurisdicción./ $2^{\circ}$ Con otros empleos o cargos dotados o retribuidos por el Estado, por las Cortes, por la Casa Real, por las provincias o por los pueblos. $3^{\circ}$ Con los cargos de Diputados provinciales, de Alcaldes, Regidores y cualesquiera otros provinciales o municipales. $4 \mathrm{o}$ Con empleos de subalternos de Tribunales o Juzgados". Artículo 112: "El ejercicio de las funciones judiciales será justa causa para eximirse de los cargos obligatorios de que se hace mención en el núm. 3. ${ }^{\circ}$ del artículo anterior. I La Autoridad a quien corresponda admitir la exención no podrá desecharla.I El que no manifestare la causa para eximirse de los expresados cargos en el término de ocho días se entenderá que ha renunciado al judicial, el cual quedará vacante de derecho". Artículo 113: "Los que ejerciendo cualquier empleo o cargo de los expresados en el artículo 111, fueren nombrados Jueces o Magistrados podrán eximirse de uno u otro cargo o empleo en el término de ocho días desde aquel en que fueron nombrados. I Si no lo hicieren, se entenderá que renuncian al cargo judicial'. I Artículo 114: "No podrán pertenecer simultáneamente a un mismo Tribunal los Jueces o Magistrados que tuvieren parentesco entre sí, dentro del cuarto grado civil de consanguineidad o segundo de afinidad.I Esta disposición será aplicable a los Jueces o Magistrados que tengan parentesco, dentro de los grados expresados, con los Fiscales, Tenientes fiscales, Abogados fiscales o auxiliares del mismo Tribunal./ Lo será igualmente cuando el parentesco, dentro de los mismos grados, fuere entre los Jueces municipales, y los de Tribunales de partido con los Fiscales o Jueces de instrucción del mismo Tribunal, o de cualquiera de ellos con los Magistrados de la Audiencia respectiva". Artículo $115:$ "En los casos a que se refiere el artículo anterior, quedará sin efecto el nombramiento hecho a favor de quien tuviere parientes, con los cuales fuere incompatible el nombrado, desempeñando funciones judiciales o fiscales, con arreglo a lo dispuesto en el artículo anterior". 
extensivo el régimen de obligatoriedad del cargo, capacidad legal para obtenerlo, duración, exenciones, incompatibilidades, reclamaciones y vacantes que sucedieren antes de terminar el tiempo ordinario de sus funciones establecidos en la ley (artículo 67).

En cuanto al nombramiento de los jueces municipales y de los suplentes, éste se confía a los presidentes de las Audiencias, en virtud de una terna que les harían llegar los presidentes de los Tribunales de partido (los jueces de primera instancia, conforme a la Circular de 30 de septiembre de 1870)durante los quince días primeros de mayo en los años en que debe realizarse la renovación (artículo 147); para confeccionar las listas de candidatos, los jueces de primera instancia podían informarse por los jueces municipales en ejercicio de aquellas personas que considerasen más idóneas o a otra autoridad o persona que les mereciese confianza (artículo 148); y en la propuesta expresarán las circunstancias que determinen la aptitud legal de los designados y otras que les recomienden para el cargo (artículo 149). En aquellas poblaciones donde hubiese más de un Tribunal de partido (juzgado de primera instancia), cada uno "hará la propuesta de los Jueces municipales que correspondan a la parte de población sujeta a su jurisdicción” (artículo 150). En el caso de los suplentes, en el momento en que el titular del juzgado municipal tome posesión o a los ocho días siguientes propondrá una terna de las personas entre las que se deba elegir suplente, enviando la propuesta al presidente de la Audiencia por conducto del juez de primera instancia, el cual la acompañará con su informe (artículo 66).

Los presidentes de las Audiencias, antes de tomar una decisión, podrían solicitar informes de los candidatos propuestos (artículo 151). Pudiese ocurrir que de los candidatos propuestos, algunos careciesen de aptitud legal y otros la tuviesen, entonces el presidente de las Audiencia podrá hacer el nombramiento de los aptos o mandar completar las ternas, sustituyendo con personas en quienes concurran los requisitos legales a los que no los tuviesen. Sí todos los propuestos careciesen de capacidad legal, entonces devolverá la terna para que se forme de nuevo (artículo 153).

Utilizada o no la facultad de informarse sobre las cualidades de los candidatos y considerando que reúnen los requisitos legales exigidos, realizará el presidente de la Audiencia el nombramiento dentro de los primeros quince días del mes de junio (artículo 152). Si entre la lista de los propuestos hubiere varios letrados, serán preferidos aquellos que hubiesen ingresado en el Cuerpo de aspirantes a la Judicatura, aunque fuesen menores de veinticinco años, aplicándose dicha disposición al caso de los suplentes (artículo 96). El nombramiento de los jueces municipales se insertará en los boletines oficiales de la provincia (artículo 154). Además de la publicación en un diario oficial, el presidente de la Audiencia remitirá el nombramiento de los jueces municipales y de sus suplentes al juez de primera instancia, quien lo pondrá en conocimiento de los juzgados municipales respectivos y en el de los nombrados (artículo 181).

Sí el juez municipal electo considera que concurre en él alguna circunstancia que le inhabilita o le exime del desempeño del cargo, podrá solicitar al presidente de la Audiencia dicha exención. Dicha solicitud la hará dentro de los ocho días 
siguiente al nombramiento a través del juez de primera instancia de la circunscripción a la que corresponde el municipio (artículo 155). En el caso de que fuera un tercero el que denunciase dicha inhabilitación o exención, lo tendrá que hacer en el mismo plazo de tiempo al presidente de la Audiencia a través del juez de primera instancia (artículo 156). El juez de primera instancia, remitirá las solicitudes y reclamaciones a la Audiencia con toda brevedad posible junto con el informe que considere procedente (artículo 157).

A la vista de los escritos presentados, el presidente de la Audiencia, oyendo al fiscal o, cuando lo considere oportuno dictará una resolución cuyo contenido será (artículo 158): la admisión de la excusa o de la reclamación, quedando sin efecto el nombramiento y procediéndose a realizar otro; la no admisión de la excusa o de la reclamación; y la averiguación y comprobación de los hechos alegados o denunciados, en cuyo caso no se dará posesión al elegido sí aún no la hubiese tomado, hasta que recaiga decisión. Tampoco se hará novedad en el caso de que el nombrado hubiese tomado posesión, esperándose a la resolución que se tome.

Las reclamaciones deben ser resueltas antes del 15 de julio, mandando publicar el presidente de la Audiencia las rectificaciones definitivas en los boletines oficiales de las provincias respectivas (artículo 159).

Sí el juez municipal supiese que está incapacitado para ejercer el cargo, podrá comunicarlo al presidente de la Audiencia en cualquier tiempo, el cual recabará informes al juez de primera instancia y oyendo a la Sala de gobierno de la Audiencia, dictará lo que procediese (artículo 160). Dicha resolución debe ser fundada en Derecho (artículo 161). Contra las resoluciones de los presidentes de las Audiencias en todos estos casos, sólo cabría recurso ante el Ministerio de Gracia y Justicia (artículo 162).

Las vacantes que se produjesen durante el bienio en que desempeñasen sus cargos los jueces municipales serían provistas por los presidentes de las Audiencias, conforme a los trámites expresados anteriormente, sin sujeción a los plazos marcados (artículo 163); los nombrados para ocupar las vacantes cesarán, si no fuesen reelegidos, al terminar los dos años por que debieron haber desempeñado el cargo sus antecesores (artículo 164).

Una vez realizado el nombramiento, el electo tomará posesión de su cargo. El juez de primera instancia ordenará que se mande prestar el juramento legalmente establecido (artículo 185) ${ }^{21}$, el cual se hará ante los jueces municipales que cesen o sus suplentes, sí el lugar no es cabeza de partido, en el lugar donde se hagan las audiencias del juzgado (artículo 189, párrafo primero). Una vez hecho el juramento, el juez municipal y sus suplentes tomarán en el mismo acto posesión (artículo 190, párrafo primero). Sí el lugar es cabeza de partido, entonces prestara el juez municipal su juramento en el juzgado de primera instancia (artículo 189, párrafo segundo), tomando posteriormente posesión de su cargo en el lugar designado para la audiencia del juzgado respectivo (artículo 190, párrafo segundo).

${ }^{21}$ La fórmula del juramento se prescribe en el artículo 188: "La fórmula del juramento que han de prestar todos los Jueces y Magistrados, sin distinción alguna, será: Guardar y hacer guardar la Constitución de la Monarquí./Ser fieles al Rey./ Administrar recta, cumplida e imparcial justicia.I Cumplir todas las leyes y disposiciones que se refieran al ejercicio de su cargo". 
La posesión será dada por quien estuviere ejerciendo las respectivas jurisdicciones, asistiendo a ella en audiencia pública el Ministerio fiscal, auxiliares y subalternos del juzgado municipal (artículo 193).

En cuanto a su ámbito competencial, el artículo 270 señalaba las atribuciones de los jueces municipales en materia civil:

$1^{a}$ Intervenir en la celebración de los actos de conciliación. Conforme al artículo 300, serían los jueces municipales del domicilio, y en su defecto los de residencia del demandado, los únicos competentes para autorizar los actos de conciliación que se promuevan en los casos que con arreglo a la ley corresponda celebrarse. En el caso de haber en la población más de un juez municipal, el primero por cuya orden se haga la citación sería el competente;

$2^{\text {a }}$ Ejercer la jurisdicción voluntaria en los casos expresamente previstos en la ley;

$3^{a}$ Conocer en primera instancia y en juicio verbal de las demandas cuyo objeto no exceda de 250 pesetas (criterio que respeto en un primer momento la posterior Ley de Enjuiciamiento civil de 1881 en su artículo 486);

$4^{a}$ Dictar a prevención las primeras providencias en las testamentarias o sucesiones intestadas, cuando proceda según las leyes, en los pueblos donde no haya juzgado de primera instancia hasta que éste tome conocimiento de ellas. Dichas providencias consistirán en todo tipo de medidas para poner en seguridad los bienes de las herencias y proveer todo lo que no admita dilación. Las actuaciones realizadas por el juez municipal tendrán que ser puestas en conocimiento inmediato al juzgado de primera instancia del partido;

$5^{a}$ Adoptar, en los casos que requieran una determinación que sin daño de los interesados no pueda diferirse, providencias interinas, dando cuenta de ello al juzgado de primera instancia del partido con remisión de los antecedentes;

6a Desempeñar las comisiones auxiliares que los jueces de primera instancia e instrucción les confieran;

$7^{\text {a }}$ Conocer de los demás juicios que les encomienden las leyes; $y$

$8^{\text {a }}$ En el caso de depósitos de personas, sí las circunstancias particulares lo exigieren, el juez municipal del lugar donde se encontrase la persona que deba ser depositada podrá decretar interina y provisionalmente el depósito, remitiendo las diligencias al juez del domicilio y poniendo a su disposición la persona depositada (artículo 309, causa 2a , párrafo $3^{\circ}$ ).

En el ámbito penal, antigua faceta que hasta entonces había estado reservada a los alcaldes de los ayuntamientos, los jueces municipales eran competentes para conocer (artículo 271):

$1^{\circ}$ En primera instancia de los juicios de faltas;

$2^{\circ}$ Instruir a prevención las primeras diligencias en las causas criminales;

$3^{\circ}$ Desempeñar las comisiones auxiliatorias que los jueces de primera instancia e instrucción les confiasen.

Los jueces municipales podían sustituir al juez de primera instancia e instrucción de la localidad en determinadas situaciones legalmente previstas (artículo 636): 
$1^{\circ}$ Cuando por cualquier circunstancia el juez de primera instancia no pudiese asistir a la audiencia;

$2^{\circ}$ Cuando tuviese que salir el juez de primera instancia del pueblo de su residencia para formar sumarias o practicar otras diligencias judiciales;

$3^{\circ}$ Cuando por impedimento justo no pudiese el juez de primera instancia practicar algunas diligencias en la cabeza de partido.

En su labor los jueces municipales podían utilizar todos los días no feriados para el despacho de los negocios. Sin embargo, la ley permitía que en las localidades con menos de quinientos habitantes pudiesen dedicar al menos dos días a la semana si bastase para ello (artículo 632). Sí el juez no pudiese asistir a la audiencia, lo avisaría a su suplente con la anticipación necesaria para que el juzgado no permanezca cerrado; sí la falta de asistencia fuese superior a cinco días, el suplente lo pondría en conocimiento del juez de primera instancia (artículo 635).

En caso de conflictos jurisdiccionales, los juzgados municipales eran uno de los órganos judiciales ante los que se podían plantear conflictos de competencia (artículo 352, 1\%), promoviéndose por medio de inhibitoria o declinatoria (artículo 357). La inhibitoria se intentaría ante el juez municipal considerado competente, pidiéndole que dirija de oficio al que se estime no serlo para que se inhiba y remita la causa (artículo 358). La declinatoria, en cambio, se propondría ante el juez municipal considerado incompetente, pidiéndole que se separe del conocimiento de la causa y la remita al tenido por competente (artículo 359). Podían ser planteadas (artículo 360): $i$ ) en los negocios civiles, por los que sean citados ante juez incompetente o puedan ser parte en el juicio promovido; y ii) en los negocios criminales, por el Ministerio fiscal, por los acusadores cuando los procedimientos hayan comenzado a su instancia, por los procesados y por los responsables civilmente del delito. También el juzgado municipal que se considere competente podrá en cualquier tiempo y en cualquier estado de la causa promover la competencia (artículo 364).

Sobre la forma de resolver las cuestiones de competencias, esta se recoge en el capítulo IV del título $7^{\circ}$ de la Ley Orgánica del Poder Judicial (artículo s 352 a 398).

Como el resto de los componentes del Poder Judicial, los jueces municipales pueden ser objeto de recusación (artículo 426), pudiendo utilizar dicho medio procesal, en los negocios civiles, los que sean o se muestren parte en ellos y, en los asuntos criminales, el Ministerio fiscal, el acusador privado o los que por él puedan ejercitar y ejerciten sus acciones y derechos, los procesados y los responsables civilmente por delito o falta (artículo 427). Las causas de recusación eran (artículo 428):

$1^{\text {a }}$ El parentesco de consanguinidad o afinidad, dentro del cuarto grado civil, con cualquiera de los intervinientes en el pleito;

$2^{\text {a }}$ El mismo parentesco, dentro del segundo grado, con el letrado de alguna de las partes que intervengan en el pleito o en la causa;

$3^{\text {a }}$ Estar o haber sido denunciado o acusado por alguna de ellas como autor, cómplice o encubridor de un delito o como autor de una falta; 
$4^{\text {a }}$ Haber sido defensor de alguna de las partes, emitiendo dictamen sobre el pleito o proceso como letrado, o intervenido en él como fiscal, perito o testigo;

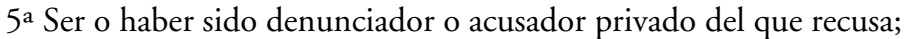

6 a Ser o haber sido tutor o curador para bienes de alguno que sea parte en el pleito o en la causa;

7a Haber estado en tutela o guardaduría de alguno de los expresados en el apartado anterior;

$8^{\mathrm{a}}$ Tener pleito pendiente con el recusante;

$9^{a}$ Tener interés directo o indirecto en el pleito o en la causa;

$10^{a}$ Amistad íntima;

$11^{\text {a }}$ Enemistad manifiesta;

Sobre la forma de resolver las acusaciones en los juicios verbales y de faltas, el procedimiento se encuentra en el capítulo $3^{\circ}$ del título $8^{\circ}$ (artículo s 461 a 471).

Los jueces municipales gozaban de la inamovilidad judicial durante los dos años que duraba su mandato (artículo 221), consistente aquella en el derecho que tienen los Jueces y Magistrados a no ser destituidos, suspensos, trasladados ni jubilados sino por alguna de las previstas en la ley (artículo 222). Solamente podían ser destituidos (artículo 223) por: i) sentencia firme en que la destitución se declare; ii) sentencia firme en que se le imponga al juez pena correccional o aflictiva, las cuales llevarán siempre consigo la destitución.

También podían ser destituidos en virtud de Real Decreto acordado en Consejo de Ministros y refrendado por el de Gracia y Justicia, previa consulta del Consejo de Estado, si incurriesen en causa de incapacidad o de incompatibilidad; si hubiesen sido corregidos disciplinariamente por hechos graves que, sin constituir delitos, comprometiesen la dignidad de su ministerio o los hagan desmerecer en el concepto público; cuando hubiesen sido absueltos de la instancia en cualquier clase de procesos, mientras la absolución por el lapso del tiempo no se convierta en libre; cuando hayan sido una o más veces declarados responsables civilmente; y cuando "por su conducta viciosa, por su comportamiento poco honroso o por su habitual negligencia, no sean dignos de continuar ejerciendo funciones judiciales" (artículo 224).

La Ley Orgánica del Poder Judicial también contempla los casos de suspensión, la cual tendría lugar por auto de tribunal competente, siendo dicho órgano judicial conforme a los artículos 228 y 276 las Audiencias (artículo 227):

$1^{\circ}$ Cuando se hubiere declarado haber lugar a proceder criminalmente contra el juez municipal por delitos cometidos en el ejercicio de sus funciones;

$2^{\circ}$ Cuando por cualquier otro delito se hubiere dictado contra el juez municipal auto de prisión o fianza equivalente;

$3^{\circ}$ Cuando sin preceder prisión ni fianza, se pidiere por el Ministerio fiscal una pena aflictiva o correccional;

$4^{\circ}$ Cuando por las correcciones disciplinarias que se le hubiesen impuesto apareciese que hayan sido una o más veces declarados responsables civilmente; y

$5^{\circ}$ Cuando se decretase disciplinariamente;

Según el artículo 229, en los tres primeros casos la suspensión durará hasta 
que recaiga en la causa sentencia de libre absolución o haya transcurrido el tiempo necesario para que se convierta en libre la absolución de la instancia, si tal hubiere sido el resultado de la causa. En el supuesto cuarto, la suspensión durará hasta que se hubiese declarado o desestimado la absolución. En el último supuesto, la suspensión se extenderá por todo el tiempo por el que se hubiere impuesto la corrección disciplinaria.

En lo referente a la jurisdicción disciplinaria a la que están sujetos los jueces municipales conforme a lo prescrito en el artículo 731, ésta es ejercida por los jueces de primera instancia (artículo 732). Son causas de corrección disciplinaria (artículo 734):

$1^{\text {a }}$ Cuando faltasen de palabra, por escrito o por obra a sus superiores en el orden jerárquico;

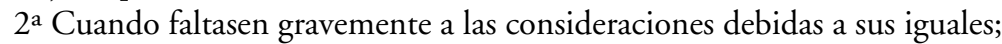

$3^{\text {a }}$ Cuando traspasasen los límites racionales de su autoridad respecto a los auxiliares y subalternos de los juzgados o a los que acudan a ellos en asuntos de justicia o a los que asistan a los estrados, cualquiera que sea el objeto con que lo hagan;

$4^{\text {a }}$ Cuando fuesen negligentes en el cumplimiento de sus deberes;

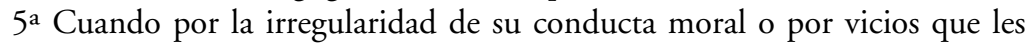
hicieren desmerecer en el concepto público comprometiesen el decoro de su ministerio;

$6^{\text {a }}$ Cuando por gastos superiores a su fortuna contrajesen deudas que diesen lugar a que se entablen contra ellos demandas ejecutivas;

$7^{\text {a }}$ Cuando recomendasen a jueces o tribunales negocios pendientes en juicio contradictorio o causas criminales;

$8^{\mathrm{a}}$ Cuando incumplan las prohibiciones contenidas en los números $3^{\circ}, 4^{\circ}, 5^{\circ}$ y $6^{\circ}$ del artículo 7 de la Ley Orgánica del Poder Judicial ${ }^{22}$;

9a Cuando sin autorización del Ministerio de Gracia y Justicia publicasen escritos en defensa de su conducta oficial o atacasen la de otros jueces o magistrados;

A los jueces municipales sólo se les impondrán, conforme al artículo 740, las correcciones de reprensión simple y de multa, que nunca será inferior a 25 pesetas y superior a 250. Las correcciones pueden ser recurridas ante las Salas de gobierno de las Audiencias (artículo 748).

${ }^{22}$ Artículo 7 de la Ley Orgánica del Poder Judicial de 1870: "No podrán los Jueces, Magistrados y Tribunales:/ $1^{\circ}$ Aplicar los reglamentos generales, provinciales o locales, ni otras disposiciones de cualquiera clase que sean que estén en desacuerdo con las leyes./ $2^{\circ}$ Dar posesión de sus cargos a los Jueces y Magistrados cuyos nombramientos no estuviesen arreglados a la Constitución de la Monarquía, a esta ley o a otras especiales./ $3^{\circ}$ Dirigir al poder ejecutivo, a funcionarios públicos o a corporaciones oficiales felicitaciones o censuras por sus actos. / $4^{\circ}$ Tomar en las elecciones populares del territorio en que ejerzan sus funciones más parte que la de emitir su voto personal.l Esto no obstante, ejercerán las funciones y cumplirán los deberes que por razón de sus cargos les impongan las leyes./ $5^{\circ}$ Mezclarse en reuniones, manifestaciones u otros actos de carácter politico, aunque sean permitidos a los demás españoles. $/ 6^{\circ}$ Concurrir en Cuerpo, de oficio o en traje de ceremonia a fiestas o actos públicos, sin más excepción que cuando tengan por objeto cumplimentar al Monarca o al Regente del Reino, o cuando el Gobierno expresamente lo ordenare". 
El juez de primera instancia es el encargado de inspeccionar y vigilar la administración de justicia en todos los términos de su partido, conforme a lo dispuesto en el artículo 710. Para facilitar su labor, una vez terminado el año judicial, los juzgados municipales del partido deben remitirle estados anuales de los negocios civiles y criminales pendientes y terminados en dicho año judicial (artículo 711). El juez de primera instancia, a su vez, enviaría a las Audiencias un resumen de lo recibido por los juzgados municipales (artículo 712).

Sí el juez de primera instancia considerase que es necesaria una inspección a un determinado juzgado municipal, debe manifestarlo al presidente de la Audiencia, para que estime lo que considere más conveniente, oído el parecer de la Sala de gobierno (artículo 716). Por otra parte, sí a la vista de las memorias presentadas por los jueces de primera instancia la Sala de gobierno de las Audiencias consideran necesaria una visita, podrían promoverla (artículo 717). Igual prerrogativa tenían las Salas de justicia de las Audiencias, quienes a la vista de los negocios civiles o criminales que conociesen, podían instar al presidente a que ordenase una visita, decisión que éste tomaría oída la Sala de gobierno (artículo 718). Sí se decretase la visita de inspección del juzgado municipal por el presidente de la Audiencia o, dentro de sus prerrogativas, por el presidente del Tribunal Supremo, el visitador elegido sería un juez de primera instancia (artículo 720). La visita de inspección tendrá por objeto el examen de todo lo que se refiera a las reglas establecidas para el gobierno del juzgado municipal y para la buena administración de justicia, a la secretaría y a todas las demás dependencias (artículo 725). Además, sí lo considerase expresamente en su orden de inspección el presidente de la Audiencia o el del Tribunal supremo, podría aquélla comprender (artículo 726):i) el registro civil; ii) el registro de la propiedad; iii) los registros de las notarías; y iv) la confrontación de la exactitud de los informes anuales que se envían sobre el estado de los pleitos.

El visitador escribiría una memoria de su visita, enviándola al fiscal del tribunal cuyo presidente la hubiere decretado (artículo 727). La junta de gobierno del tribunal, a la vista del informe del fiscal, adoptará las medidas que quedan dentro de sus atribuciones y, cuando no alcanzasen, propondría al Gobierno lo que estimase necesario (artículo 728).

Para terminar con este apartado, se reconoce también la responsabilidad criminal y civil (artículo s8, 245 y260) de los jueces en el ejercicio de sus funciones cuando, en el primer caso, cometiesen un delito previsto en el Código Penal o en leyes especiales, o, en el segundo caso, cuando produjesen daños y perjuicios causados a particulares, corporaciones o al Estado por infringir las leyes por negligencia o ignorancia inexcusable.

Como auxiliares de los jueces municipales la Ley Orgánica del Poder Judicial contempla la figura de los secretarios de juzgados municipales (artículo 473).

En cada juzgado municipal habría un secretario, quien autorizaría todos sus actos, así como un suplente para los casos de vacante, enfermedad, ausencia, incompatibilidad, recusación u otro cualquier impedimento del secretario titular (artículo 494).

El secretario debía reunir las condiciones previstas para ser juez o magistrado, 
no estar comprendido en los casos de incapacidad previstos en la ley y ser de buena conducta moral, pero, solamente en el caso de los secretarios de juzgados municipales, sí podía ejercer un cargo o empleo público (artículo 474), "cuyo desempeño sea conciliable con él, en las poblaciones que no lleguen a 500 vecinos"; si se excediese de ese número de habitantes, entonces "los expresados cargos serán incompatibles con todo empleo, cargo o comisión retribuidos por el Gobierno, por la provincia o por los pueblos" (artículo 497).Se prefería para los puestos de secretario y de su suplente a aquellos que tuviesen conocimientos jurídicos adquiridos en estudios profesionales o en la práctica de negocios judiciales (artículo 495).

El futuro secretario de juzgado municipal y su suplente serían nombrados por los jueces de primera instancia a propuesta en terna por los jueces municipales (artículo 496, párrafo primero), tal como se había hecho anteriormente. Su dotación consistiría en los derechos que estuviesen señalados en los aranceles (artículo 496, párrafo $2^{\circ}$ ).

Los secretarios de los juzgados municipales antes de tomar posesión de su cargo prestarían juramento ante el juez municipal de guardad la Constitución, ser fieles al rey y de cumplir con diligencia las leyes que se refieren al ejercicio de su cargo (artículo s 478 y 479), dando a continuación el juez la posesión de su cargo (artículo 480). A partir de entonces, el secretario tiene la obligación de residir en el pueblo donde ejerce sus funciones, no pudiendo ausentarse de él sin licencia del juez, pues en caso contrario podría ser corregido disciplinariamente o, perdería el cargo, si la ausencia fuera superior a tres meses (artículo 483).

Competencias genéricas de los secretarios eran (artículo 481):

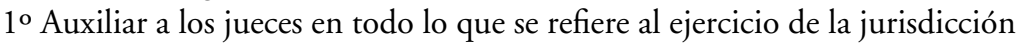
voluntaria o contenciosa;

$2^{\circ}$ Guardar secreto en todas las materias y casos de su cargo que lo exigieren;

$3^{0}$ Anotar en los autos los días y las horas, en los casos en que los términos sean fatales, cuando se les presenten los escritos;

$4^{\circ}$ Anotar igualmente los días en que las partes tomen y devuelvan los autos y en que sin devolución de estos presenten escritos;

$5^{\circ}$ Dar oportunamente cuenta de todas las pretensiones que se les presenten en los negocios en que actúen, siendo responsables de las dilaciones inmotivadas en que incurran;

$6^{\circ}$ Extender fielmente y autorizar con su firma las actuaciones, providencias, autos y sentencias que pasen ante ellos;

$7^{\mathrm{o}}$ Custodiar y conservar asiduamente los procesos y los documentos que estuvieren a su cargo;

$8^{\circ}$ No dar copias certificadas o testimonios sino en virtud de providencia del juzgado;

$9^{\circ}$ Llevar siempre al corriente los libros que prevengan las leyes y disposiciones reglamentarias;

$10^{\circ}$ Ser imparciales con todos los que tengan negocios pendientes en sus secretarías; y

$11^{\circ}$ Cumplir con las demás obligaciones que les impongan las leyes y las dis- 
posiciones reglamentarias (por ejemplo, las derivadas de la Ley y del Reglamento del registro civil).

Los secretarios podrían separados de sus cargos por cualquiera de las causas previstas para los jueces y magistrados en la ley (artículo 485). La separación deberá ser decretada por el juez de primera instancia (artículo 488), no cabiendo recurso contra dicha resolución (artículo 489). También podían ser objeto de recusación (artículo 557), conociendo de ella el juez municipal, sí sólo hubiese un juzgado de este tipo en la localidad; en el caso de haber dos, instruiría y fallaría el juez del juzgado al que no perteneciera el recusado; y si hubiere tres o más juzgados, entonces sería el que siguiese en el orden oficial a aquel a que perteneciese; sí perteneciese al último en orden, entendería de la recusación el primero (artículo 560).

Además del secretario, el juzgado municipal sería auxiliado por un subalterno, que recibiría el nombre de alguacil, habiendo al menos uno de ellos en el juzgado (artículo 566). Si el juez municipal estimase que necesitase de más, lo propondría al juez de primera instancia, quien remitiría la propuesta al presidente de la Audiencia para que adoptase la resolución más conveniente (artículo 567). Los requisitos legales exigidos al candidato a ocupar la plaza de alguacil eran ser mayor de veinticinco años, saber leer y escribir, buena conducta y no haber sufrido penas correccionales ni aflictivas (artículo 570, párrafo $1^{\circ}$ ). Sí se nombrase algún candidato que no cumpliese dichos requisitos y el juez municipal no dejase sin efecto su nombramiento como estipula el artículo 572, entonces decretará la plaza vacante el juez de primera instancia (artículo 573). En lo referente a la retribución, será aquella que indiquen los aranceles judiciales (artículo 579).

El juez municipal tiene jurisdicción disciplinaria sobre los auxiliares de su juzgado (artículo 751) en los casos expresados en el artículo 734, pudiendo establecer las correcciones de advertencia, apercibimiento, multa que no excediese de 100 pesetas, reprensión a puerta cerrada y suspensión de empleo y privación de sueldo y de emolumentos (artículo 752). Contra dichas resoluciones los auxiliares pueden recurrir al juez de primera instancia del partido (artículo 753). También tiene jurisdicción disciplinaria el juez municipal contra los abogados y procuradores cuando (artículo 756): $i$ ) en el ejercicio de su profesión, faltasen oralmente, por escrito o de obra al respeto debido a los juzgados y tribunales; ii) en la defensa de sus clientes, se descompusieren contra sus colegas de una manera grave e innecesaria para aquella; y iii) llamados al orden en las alegaciones orales, no obedecieren al que presidiere el tribunal.

Contra dichas correcciones los abogados y procuradores pueden recurrir ante la Audiencia (artículo 760).

El artículo 766 de la Ley Orgánica del Poder Judicial de 1870 prevé la existencia de fiscales en los juzgados municipales, cargo que no da categoría en el orden del Ministerio fiscal (artículo 767).

Los requisitos legales exigidos para ocupar la plaza de fiscal en el juzgado municipal son los mismos que los que deben concurrir en los jueces municipales (artículo 776), siendo preferidos para ocupar el puesto de fiscal aquellos que sean abogados a los que no lo sean, aunque fuesen menores de veinticinco años (artículo 777). En cuanto al nombramiento, juramento y posesión de los 
fiscales de los juzgados municipales se aplican las mismas reglas que rigen para los jueces municipales, con la excepción de que las atribuciones que se otorgan a los jueces de primera instancia y a los presidentes de las Audiencias deben ser atribuidas a los fiscales que dependen de dichos órganos judiciales (artículo 790). El nombramiento del fiscal y de su suplente debe ser comunicado por el fiscal de la Audiencia a los juzgados de primera instancia del partido, los cuales lo pondrán en conocimiento de los juzgados municipales respectivos, encargándoles que les reciban juramento y en el mismo acto les den posesión en el lugar destinado a la audiencia (artículo 794).

En lo referente a honores y dotación, los fiscales municipales usarían en los actos oficiales una medalla semejante a la señalada a los jueces municipales, conforme al modelo que aprobase el Gobierno (artículo 812) y percibirían los honorarios que señalasen los aranceles judiciales (artículo 816). En todas las demás materias, se establece lo ordenado en el título XX de la Ley Orgánica del Poder Judicial de 1870 sobre el régimen del Ministerio fiscal.

Así concluye la regulación de la justicia municipal en la Ley Orgánica del Poder Judicial de 1870. La ley establecía definitivamente la separación de la justicia municipal de los órganos de la administración local, al perder los alcaldes la facultad de juzgar los casos de faltas; sin embargo, la politización de la justicia municipal no desapareció a pesar de dejar en manos de los presidentes de las Audiencias la designación de los candidatos.

\section{REFORMAS POSTERIORES A FINALES DEL SIGLO XIX ${ }^{23}$}

La reforma judicial realizada en la Metrópoli tuvo su correlativo en Ultramar por medio del Decreto de 25 de octubre de 1870. Preveía el Decreto la creación de un juzgado de paz en cada término municipal (artículo 1) y, mientras el Gobierno no previniese la creación o instalación de los nuevos juzgados municipales en los lugares donde no existían en ese momento "seguirán éstos sujetos (los términos municipales) a las Autoridades judiciales que en ellas existan" (artículo 4). Por último, indicaba que en los juicios de faltas, haría de fiscal el procurador síndico si en el término municipal hubiese ayuntamiento (artículo 12). Nada más decía el Decreto, permaneciendo vigente lo legislado años atrás.

Tras el "Sexenio Revolucionario" y la restauración de los Borbones en la persona de Alfonso XII, las reformas en el panorama de la justicia municipal no tuvieron la importancia que en los períodos anteriores. La primera norma a destacar fue el Real Decreto de 2 de junio de 1883, ordenando que en aquellas poblaciones donde hubiese Audiencias territoriales o más de un juzgado de primera instancia los cargos de juez municipal debían de ser ocupados por abogados, debiendo reunir las condiciones requeridas para ser juez de término según lo dispuesto en el artículo 42, 30 de la Ley adicional de 14 de octubre de 1882 a la Orgánica del Poder Judicial de 1870 (artículo 1), es decir, el abogado que, llevando ocho

\footnotetext{
${ }^{23}$ Sobre la justicia municipal a finales del siglo XIX, véanse: LASSO GaITE, J. F., cit. (n. 1); Lorente Sariñena, M.- Martínez Pérez, F. - Solla Sastre, M. J., cit. (n. 8); Montero ArocA, J., cit. (n. 8).
} 
años de ejercicio en la abogacía, haya pagado alguna cuota de contribución de las comprendidas en la mitad superior de la escala respectiva en los cuatro años últimos, o desempeñando durante dos o más años, cargo de juez o fiscal municipal en capital de provincia o de sustituto del Ministerio fiscal de las Audiencias. Sí no pudiera encontrarse abogados que cumplieran esos requisitos, entonces, el artículo 2 del Real Decreto establecía que los candidatos a jueces municipales deberían reunir los requisitos establecidos en el artículo 41, párrafo último, de dicha Ley adicional, para ser juez de ascenso ${ }^{24}$. Hechos los nombramientos por los presidentes de las Audiencias en los plazos legalmente establecidos, los remitirían al Ministerio de Gracia y Justicia con copia certificada de las hojas de méritos y servicios de los candidatos, siendo publicada la lista de los nombramientos en la Gaceta de Madrid (artículo 3).

El mismo criterio de designar profesionales del Derecho para la justicia municipal lo encontramos en una Real Orden del Ministerio de Gracia y Justicia de 23 de abril de 1893, estableciendo dicha norma un orden de preferencia en las propuestas que deben hacer los jueces de primera instancia o los fiscales de las Audiencias provinciales para los nombramientos de juez o fiscal municipal (artículo 1):

$1^{\text {o }}$ Funcionarios excedentes de las carreras judicial y fiscal, por orden de su categoría;

$2^{\circ}$ Cesantes o jubilados con aptitud para volver al servicio;

$3^{\circ}$ Aspirantes a la judicatura, por el orden de su calificación;

$4^{\circ}$ Licenciados en Derecho que no ejerzan la profesión en el foro, si hay motivos racionales para creer que no han abandonado la ciencia de las leyes hasta el punto de carecer de la competencia que hace suponer su título académico;

$5^{\circ}$ Abogados en ejercicio; y

60 A falta de alguno de los anteriores en la localidad, se podrá proponer y nombrar a aquellas personas que no tengan las cualidades expresadas;

Los funcionarios excedentes, cesantes y los aspirantes a la judicatura de la Península o Baleares podían presentar su solicitud antes del 5 de mayo ante sus respectivos juzgados o fiscalías provinciales o ante los presidentes o fiscales de las Audiencias, quienes se lo comunicarían a los jueces de primera instancia; para los residentes en Canarias, el plazo terminaba el día 12 del mismo mes (artículo 3).

Sí los jueces de primera instancia o los fiscales de la Audiencia provincial o los presidentes y fiscales de las Audiencias territoriales creyesen inconveniente

${ }^{24}$ Artículo 41, último párrafo: "Los Juzgados de ascenso y Abogacias fiscales de Audiencias de lo criminal se proveerán con arreglo a los siguientes turnos: [...].l En la cuarta vacante podrá el Gobierno ascender al Juez de entrada que considere más digno, cualquiera que sea el puesto que ocupe en el escalafón; o nombrar para ocuparla, bien a un Secretario de Audiencia de lo criminal que reuna las condiciones señaladas en el artículo 53, bien a un funcionario cesante de categoría igual a la de la vacante, bien a un Abogado que hubiese ejercido su profesión por seis años, con buen concepto y pagado una cuota de contribución que no sea de las tres más bajas, en los cuatro últimos años". Artículo 53: "Los Vicesecretarios podrán ser nombrados Jueces de entrada después de haber desempeñado durante dos años su cargo y los Secretarios podrán serlo desde luego.l Para poder estos ser nombrados Jueces de ascenso necesitarán llevar dos años en el ejercicio de su cargo y tener al menos cuatro de carrera, pudiendo serlo de término si llevasen seis". 
seguir la preferencia ordenada, entonces expresarán al elevar la propuesta o en el expediente de nombramiento los motivos que lo justifiquen (artículo 2). En todo caso, dice el artículo 4: "se aseguren los que han de hacer las propuestas respecto a los que han de figurar en ellas, de sus condiciones de honradez, rectitud de carácter, imparcialidad, independencia y demás cualidades necesarias para que sean por ellas una garantía de la paz pública, de la justicia y de la observancia de las leyes, y excluyan a quienes no ofrezcan la seguridad de tales cualidades; y que los Presidentes y Fiscales de las Audiencias territoriales[...] hagan en su caso igual exclusión”. Un año más tarde, la Real Orden de 15 de noviembre de 1894 confirmaba la norma anterior (artículo 1) y, que, en cuanto al orden de preferencia dentro del grupo de los funcionarios excedentes, se tuviera en cuenta la antigüedad (artículo 2), y eliminaba también los plazos de presentación de instancias cuando ocurriese alguna vacante (artículo 3).

Sin embargo, aunque fue dictada con el carácter de aclarar la aplicación de la Real Orden de 23 de abril de 1893, la Real Orden de 21 de agosto de 1895, suponía un paso atrás en la tecnificación del juez municipal. Según afirmaba el ministro de Gracia y Justicia del momento, Romero Robledo, no había que confundir la recomendación con el mandato en el caso de la designación de los jueces municipales, pues la ley buscaba jueces honrados, imparciales e independientes, fuesen o no letrados. La Real Orden de 1893 tuvo sólo el carácter de un ruego, consejo o recomendación para los presidentes de las Audiencias, no pudiendo vulnerar lo dispuesto en el artículo 121 de la Ley Orgánica del Poder Judicial sobre las cualidades que debían tener los encargados de impartir la justicia en el ámbito local. Añadía que la justicia municipal tenía como misión "antes que fallar sobre contiendas, hacer posible la concordia y procurar alejar la necesidad de reprimir transgresiones legales impidiendo querellas, y buscando en el radio de su jurisdicción $y$ de su competencia que impere la armonía y la conciliación en las relaciones de intereses y de personas. Con tan hermoso propósito, la ley exige en los encargados de la justicia municipal las condiciones que más faciliten el ejercicio amigable y paternal de sus funciones".

"Por esto -sigue la Real Orden-, no es la capacidad jurídica la que la ley en primer término busca, sino la capacidad moral, la que se funda en la honradez, en la rectitud, en la entereza y en la imparcialidad reconocidas; cualidades que no se prueban en expedientes ni se presumen por la posesión de titulos académicos, sino que la opinión pública certifica y pregona, y los Presidentes y Fiscales de las Audiencias estiman en su conciencia en el momento de hacer la designación o el nombramiento de tales funcionarios".

El espíritu de las preferencias en técnicos en Derecho que había impulsado la Real Orden de 1893 subsistió con la promulgación del Real Decreto de 10 de abril de 1899, obra del entonces ministro de Gracia y Justicia Manuel Durán y Bas, aprovechando el personal excedente de las carreras judicial y fiscal de Ultramar ocasionado tras el "desastre del 98”. Así, en los nombramientos de jueces y fiscales municipales se preferiría a los funcionarios excedentes de las carreras antedichas, por orden de su categoría y, dentro de ésta, por su antigüedad de servicio en la carrera; en su defecto los aspirantes a judicatura y licenciados en Derecho "en 
la forma que previenen las disposiciones vigentes". A falta de todos ellos, se podría proponer y nombrar a las personas que no reuniesen dichas condiciones (artículo 1). Los funcionarios excedentes podrían solicitar las plazas de jueces o fiscales municipales ante los juzgados y fiscalías antes del 5 de mayo, debiendo estar domiciliados en el pueblo donde han de ejercer su cargo (artículo 2); como una muestra de la preferencia en técnicos, el Ministerio de Gracia y Justicia remitiría a los presidentes y fiscales de las Audiencias territoriales una relación de los funcionarios excedentes que se considerase que pudiesen obtener los beneficios establecidos en el presente decreto (artículo 3). Pero no sólo habría preferencias para los cargos de jueces y fiscales municipales. El artículo 4 ordenaba que la provisión interina de las secretarías de los juzgados municipales (junto con las secretarías de gobierno y de Salas de justicia y relatorías del Tribunal Supremo y de las Audiencias, vicesecretarías del Tribunal Supremo y escribanías de actuaciones) podían conferirse a dichos funcionarios excedentes por el orden que se indicaba en el artículo 1 Como puede observarse en todas estas normas posteriores a la Ley Orgánica del Poder Judicial de 1870, parecía que iba a triunfar el criterio técnicojurídico en el desempeño de la justicia municipal.

\section{BibLIOGRAFÍA}

Abeberry MagesCas, X., Le gouvernement central de l Espagne sous Joseph Bonaparte (1808-1813), effectivité des institutions monarchiques et de la justice royale (Paris, 2001).

Abella, F., Manual del Registro civil (5a edición, Madrid, 1885).

Álvarez Cora, E., La arquitectura de la justicia burguesa. Una introducción al enjuiciamiento civil en el siglo XIX (Madrid, 2002).

Arrazola, L., Enciclopedia española de Derecho y Administración o Nuevo Teatro Universal de la Legislación de España e Indias (Madrid, 1849), II.

Barnuevo, J. M., Deben valerse los Jueces municipales de asesor cuando practique algún embargo preventivo, en Revista General de Legislación y Jurisprudencia, 43 (1873).

CésPedes y Orellano, J. M., Elementos teórico-prácticos de procedimientos civiles con aplicación a la isla de Cuba(La Habana, 1862), I.

Совоs Gavala, R., El juez de paz en la ordenación jurisdiccional española (Madrid, 1989).

De los Ríos, J. M., Código español del reinado intruso de José Napoleón Bonaparte (Madrid, 1845).

Fernández, T. R. - Santamaría, J. A., Legislación administrativa española del siglo XIX (Madrid, 1977).

García Rodríguez, H., De la justicia municipal a la justicia de paz, en Revista Vasca de Derecho Procesal y Arbitraje - Zuzenbide Prozesalata Arbitraria Euskal Aldizkaria, 2 (1990).

Gómez Bravo, G., Derecho y poder. Desarrollo y obstrucción a la nueva justicia en la primera mitad del siglo XIX, en Derechos y Libertades, 16 (2007).

GonZÁlez Alonso, B., El corregidor castellano (1348-1808) (Madrid, 1970).

LASSO Gaite, J. F., Crónica de la codificación española, I: Organización judicial (Madrid, 1998). 
Lorente Sariñena, M. (coordinadora), De justicia de jueces a justicia de leyes, Hacia la España de 1870 (Madrid, 2006).

Lorente Sariñena, M. - Martínez Pérez, F. - Solla Sastre, M. J., Historia legal de la justicia en España (1810-1978) (Madrid, 2012).

Martínez Alcubilla, M., Manual de las atribuciones de los jueces de paz (Madrid, 1859).

Diccionario de la Administración española, peninsular y ultramarina (2a edición, Madrid, 1869), VIII.

MAS y ABAD, C., Manual del juez de paz (Madrid, 1857).

Mercader Riba, J., José Bonaparte, rey de España (1808-1813). Estructura del Estado español bonapartista (Madrid, 1983).

Montero Aroca, J, La justicia municipal, en Estudios de Derecho Procesal (Barcelona, 1981).

Muñoz de Bustillo, C., Primera experiencia constitucional en Andalucía. Bayona (1808-1811) (Sevilla, 2010).

Ortiz DE ZÚNIIGA, M., El libro de los alcaldes y ayuntamientos (2a edición, Madrid, 1849).

Práctica general forense (4a edición, Madrid, 1861).

PAREDES, J., La organización de la justicia en la España liberal. Los orígenes de la carrera judicial, 1834-1870 (Madrid, 1991).

Puyol Montero, J. M., La reforma judicial de José Bonaparte, en e-S Legal History Review, 7 (2009).

Sainz Guerra, J.,La Administración de justicia en España (1810-1870) (Madrid, 1992). 
